\title{
Martial Law and the Rule of Law in the Eastern Cape, I830-I 880
}

In I 8 I 4, the Cape Colony was ceded by the Dutch to the British. The territory extended as far as the Great Fish River to the east and the Koussie River to the north. This land was home to approximately 60,000 people, of whom 27,000 were white descendants of Dutch and Huguenot settlers, and 17,000 indigenous Khoi, or 'Hottentot' people. For much of the nineteenth century, the border of the Cape colony was unsettled, as a series of 'frontier wars' was fought between the colonists and the Xhosa, which would ultimately lead to the subjection of the Africans and their incorporation into the empire. Martial law was declared in the Eastern Cape during these wars in I 835, I 846 , I 850 and I 877 . These periods of war and rebellion saw many people being detained either as prisoners of war or as rebels, and many more imprisoned after briefs trials in martial law courts. The Cape frontier would give the Colonial Office its first African experience of imprisonment in times of emergency. The wars here would raise questions about the nature of martial law and its relationship with ordinary civilian law. They would also raise questions about how far any idea of the rule of law would act as a constraint on official policy.

The Cape Colony was a settler colony, with an established judicial system. The Roman-Dutch law brought by the original settlers was the law applied by a Supreme Court constituted under royal charter in I 827 to succeed an earlier court of justice in the Cape. The new court, which used a common law judicial and procedural framework, was open to those who had been advocates in the preceding court, and to 
those who had received a legal education in England, Ireland or Scotland. Since Roman-Dutch law offered a remedy analogous to habeas corpus - the interdict de homine libero exhibendo - its courts offered the same kind of tools available in the metropolis to check abuses of power; and the court came to be staffed by a number of judges keen to defend a liberal view of the rule of law. At the same time, however, the frontier was a place of jurisdictional confusion. It was often unclear whether the territory over which colonial officials sought to exert control had come under the jurisdiction of the Cape, or had been conquered by the crown (and so was subject to the crown's discretionary rule), or remained an independent polity. It will be seen in what follows that officials, both in the locality and in the metropolis, were constantly aware of the legal problems posed by their actions. Legal niceties were not allowed to stand in the way of conquest, for British colonial governors were prepared to tear up treaties when it suited them, and to assume control over new territories without having a clear idea of the legal basis for their action. However, when it came to the incarceration of enemies and rebels, questions of legality were apt to impinge, and to constrain.

\section{Four Wars and Two Rebellions}

In I $820,4,000$ British migrants were sent to settle the frontier district of Albany, from which the Xhosa had been expelled in I 8I 2. In order to create a buffer zone beyond this district, Governor Charles Somerset made a verbal treaty in I 8 I9 with the Rharhabe Xhosa chief Ngqika, ${ }^{\text {I }}$ under which he agreed to keep his people out of the area between the Keiskamma and the Great Fish Rivers which was now declared to be 'neutral territory'. ${ }^{2}$ In I 829, the year of Ngqika's death, another buffer

${ }^{\mathrm{I}} \mathrm{He}$ (and his people) were also known as Gaika by the Europeans.

2 Timothy Keegan, Colonial South Africa and the Origins of the Racial Order (London: Leicester University Press, I996), pp. I29-I3I. For broader histories of the events discussed below, see in addition John S. Galbraith, Reluctant Empire: British Policy on the South African Frontier I834-1854 (Berkeley and Los Angeles, University of California Press, 1963); Noel Mostert, Frontiers: The Epic of South Africa's Creation and the Tragedy of the Xhosa People (London, Jonathan Cape, I992); Clifton C. Crais, White Supremacy and Black Resistance in Pre-industrial South Africa (Cambridge, Cambridge University Press, I992); Elizabeth Elbourne, Blood Ground: Colonialism, Missions and the Contest for Christianity in the Cape Colony and Britain, I799-I853 


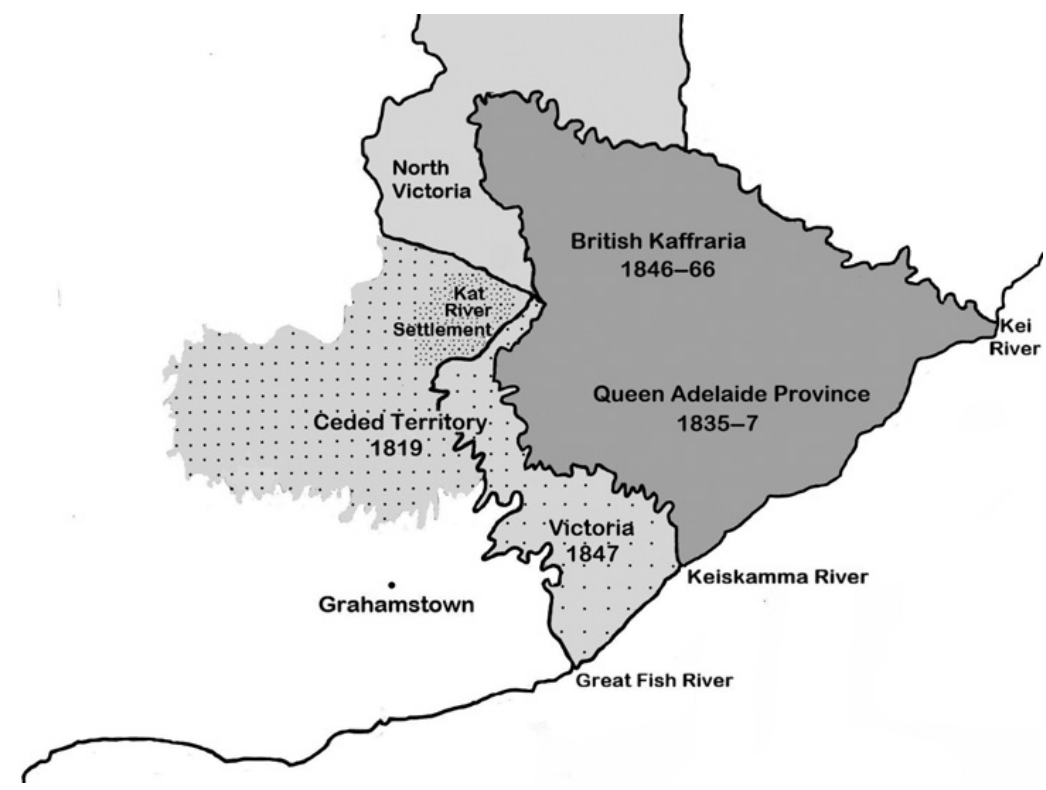

MAP I The Eastern Cape, I8I9-I866

against the Xhosa was created when Governor Lowry Cole and his Commissioner General of the Eastern Districts, Andries Stockenström, established the new Kat River Settlement, in which they settled 3,000 free people of colour, made up of 'Hottentots' (Khoi people), as well as people of mixed Khoi-Dutch descent. This settlement was within the Cape Colony, bordering the neutral space which came to be called the 'Ceded Territory'. 3 To make room for the new settlement, Ngqika's followers - led by his eldest son Maqoma, acting as regent for his heir

(Montreal and Kingston, McGill-Queen's University Press, 2002); Richard Price, Making Empire: Colonial Encounters and the Creation of Imperial Rule in NineteenthCentury Africa (Cambridge, Cambridge University Press, 2008); Alan Lester, Imperial Networks: Creating Identities in Nineteenth-Century South Africa and Britain (London, Routledge, 200I); J. B. Peires, The House of Phalo: A History of the Xhosa People in the Days of Their Independence (Johannesburg, Ravan Press, I98I); and J. B. Peires, The Dead Will Arise: Nongqawuse and the Great Xhosa Cattle-Killing Movement of I 856-7 (Johannesburg, Ravan Press, I989).

3 Robert Ross, The Borders of Race in Colonial South Africa: The Kat River Settlement, I 829-I856 (Cambridge, Cambridge University Press, 20I3); and Tony Kirk, 'Progress and Decline in the Kat River Settlement', Journal of African History, vol. I4:3 (I973), pp. 4II-428 at pp. 4I2-4I3. 
Sandile - were expelled from these lands, to which they had been allowed to return to graze their cattle in the I $820{ }^{4}{ }^{4}$

The frontier continued to be unsettled. As a result of conflicts over land in the Ceded Territory, a new frontier war - the sixth in a series dating back to the I 790 - broke out after Maqoma invaded the colony with I 2,000 men in December I 834. Governor Benjamin D'Urban sent Col. Harry Smith to quell the disturbances, and on 3 January I 835 proclaimed martial law in a number of districts in the Eastern Cape. ${ }^{5}$ By May, the Xhosa had been repelled. On Io May I 835, with victory assured, D'Urban (who had fallen under the influence of settlers who wanted further expansion in the area) declared that the eastern border of the Cape Colony would now be the Kei River. ${ }^{6}$ The new territory between the Keiskamma and Kei Rivers, acquired by conquest, would be called Queen Adelaide Province. On I 6 June I 835, martial law was proclaimed in this province. Abandoning an initial ambition to expel the Xhosa to make room for settlers, D'Urban proposed to sign treaties under which the Africans (including the Ngqika) would be received as subjects of the English crown, to live under English laws. ${ }^{7}$ However, this policy was vetoed by the Secretary of State, Lord Glenelg, an evangelical whose views were more in line with humanitarians at the Cape, who stated that 'any extension of His Majesty's dominions by conquest or cession is diligently and anxiously to be avoided'. ${ }^{8}$ A new series of treaties was accordingly negotiated, under which the British withdrew forts from the Ceded Territory (much of which was loaned 'in perpetuity' to the Africans) and renounced sovereignty over the Province of Queen Adelaide in February 1837. During this time, martial law remained in place for different periods in different places. It was lifted in the districts of Graaff-Reinet, George and Beaufort and part of the district of Uitenhage on I 7 June I 835 , but remained in place

${ }^{4}$ Mostert, Frontiers, pp. 6I2-625; and Eric A. Walker, A History of South Africa (London, Longman, Green \& Co., I935), p. I89.

5 PP I835 (252) XXXIX. 53 I, enc. 4 in No. 42, p. I30. Martial law was proclaimed in Albany, Somerset, Uitenhage, Graaff-Reinet, George and Beaufort.

${ }^{6}$ PP I 836 (279) XXXIX. 277, enc. I2 (A) in No. 3, p. 4I.

7 PP 1836 (279), enc. 5 in No. 9, p. 95.

${ }^{8}$ PP I836 (279), No. 5, p. 59 at p. 68; PP I837 (503) XLIII. 319, No. 23, p. 54; W. M. Macmillan, Bantu, Boer and Briton: The Making of the South African Native Problem, revised ed. (Oxford, Oxford University Press, I963), pp. I75-I76; and Galbraith, Reluctant Empire, pp. I30-I3 I. 
in Port Elizabeth, Albany and Somerset until 9 July I 836. It remained in place in the new province until I 8 August I 836 .

Any sense of security which the Xhosa may have obtained from these treaties was undermined with the arrival of Sir Peregrine Maitland as Governor in March I844. By this point, the restraining influence of humanitarian philanthropists at the Cape had diminished significantly. Maitland thought the treaties placed 'unnecessary restrictions on the colonial farmer' - who wanted access to the Ceded Territory to graze sheep - and so imposed new ones on the Xhosa chiefs. ${ }^{\text {IO }} \mathrm{He}$ was particularly keen to subdue the Ngqikas, who 'have not only been very perfidious neighbours [...] but have retrograded exceedingly in civilization'. ${ }^{\text {II }}$ With this in mind, he decided to build a fort on the eastern bank of the Keiskamma river, outside the Ceded Territory. This was a highly provocative act, which the British later saw as a pretext for the war which followed. ${ }^{\text {I2 }}$ A seventh frontier war - or the 'War of the Axe' - began on I April I 846, when Lieutenant-Governor John Hare, 'no longer able to contain the tide of bellicosity rising round him', ${ }^{\mathrm{I} 3}$ ordered an invasion of the Ceded Territory, in response to the violent rescue by the Xhosa of a prisoner being marched to Grahamstown to be tried for the theft of an axe. Hare's pre-emptive strike had not been properly prepared, and his forces were soon driven back by the Ngqikas, who streamed into the colony, and threatened to overcome the colonial forces. ${ }^{\mathrm{I} 4}$ In response, on 2I April I 846, Hare proclaimed martial law in the eastern districts, in order to assemble a force of burghers and Khoi to fight the Xhosa, and on the following day, Maitland proclaimed martial law in force throughout the whole Colony for all cases, and in all matters connected with the assembling, embodying, conducting, and supplying Her Majesty's forces'. ${ }^{\text {15 }}$

Following the proclamation of martial law, the tide of the war began to turn in favour of the British. However, it soon fell into a stalemate,

9 Maitland to Lord Stanley, 7 December I 844 , CO 48/245 f. 54 .

Io Macmillan, Bantu, Boer and Briton, p. 282; and Galbraith, Reluctant Empire, p. I68. See $\mathrm{CO}_{4} 8 / 245 \mathrm{ff} .73 \mathrm{ff}$. for a comparison of the terms of the treaties.

${ }^{\text {II }}$ Maitland to Lord Stanley, 7 December I 844, CO $48 / 245$ f. 54 .

${ }^{12}$ Mostert, Frontiers, p. 862; and Macmillan, Bantu, Boer and Briton, p. 287. See also PP I 85 I (635) XIV. I, pp. 3I3-3I4.

${ }^{13}$ Keegan, Colonial South Africa, p. 2I 5. $\quad{ }^{14}$ Mostert, Frontiers, pp. 875-878.

${ }^{15}$ PP I 847 (786) XXXVIII. 27, Nos. 8-II, pp. I2I-I 23. 
with the British unable to engage the Xhosa in battle, and both sides becoming increasingly exhausted. Faced with starvation of their cattle, the Xhosa eventually gave up the fight. On 26 October I846, Maqoma surrendered to the government, followed by Sandile on I7 December. ${ }^{16}$ On I 3 January I847, with order apparently restored, Maitland revoked martial law. ${ }^{17}$ One week later, as he prepared to return home, he wrote to Grey (the new Secretary of State, appointed in I 846) that every chief in the area - save the T'Slambie chief Phato had given in their arms, and registered as a British subject. ${ }^{18}$ In fact, as his successor, Sir Henry Pottinger, perceived, Maitland's confidence was premature. Pottinger thought that if Phato were not brought to submission, other chiefs, notably Sandile, might again become restive. ${ }^{\text {I9 }}$ The war was revived, with a (failed) expedition being sent out in April I 847 to locate Phato. A large body of troops was also sent out to apprehend Sandile, who was proclaimed a rebel in August. ${ }^{2 \circ} \mathrm{A}$ merciless campaign against him made Sandile ready to come to terms by October, and, after two months' imprisonment, he made a formal submission to another new Governor, Sir Harry Smith.

The colonial borders were now redrawn again. By a proclamation of 17 December 1847 , all existing treaties with the Xhosa were abrogated, and the boundary of the Cape Colony was defined to include the former Ceded Territory, as well as other areas further north, to constitute an area now called the Division of Victoria. ${ }^{2 \mathrm{I}} \mathrm{Six}$ days later, at King William's Town, Smith read this proclamation out to the assembled Xhosa chiefs, who now included Phato. Having watched them all touch his staff of peace to signal their future intentions, he made each chief kiss his boot and acknowledge him as paramount chief. ${ }^{22}$ Smith then read a second proclamation, which declared the area between the Keiskamma and Kei Rivers to be vested in the Queen as

${ }^{16}$ Peires, House of Phalo, p. I 5 I; and Johannes Meintjies, Sandile: The Fall of the Xhosa Nation (Cape Town, T. V. Bulpin, I97I), pp. I 57-I 58.

${ }^{17}$ PP I 847-48 (9I2) XLIII. I, enc. in No. 4 (G), p. $20 .{ }^{18}$ PP I $847-48$ (9I2), No. 4, p. 8.

19 PP I 847-48 (9I 2), No. Iо, p. 27; and Mostert, Frontiers, p. 9 I 6.

${ }^{20}$ Mostert, Frontiers, p. 92I; Basil le Cordeur and Christopher Saunders, The War of the Axe, I847 (Johannesburg, Brenthurst Press, I98I), p. II9; Macmillan, Bantu, Boer and Briton, p. 298; and PP I 847-48 (9I2), enc. No. 6 in No. 33, p. I 26.

${ }^{21}$ PP I 847-48 (969) XLIII. I 57, enc. I in No. 6, p. 22.

22 A. L. Harington, Sir Harry Smith: Bungling Hero (Cape Town, Tafelberg, I980), p. I03; and PP I847-48 (969), No. 7, p. 24. 
a separate colony of 'British Kaffraria'. This territory would be held by the chiefs under such rules and regulations as the High Commissioner 'shall deem best calculated to promote the civilization, conversion to Christianity, and general enlightenment of the benighted human beings subject to her rule'. ${ }^{23}$ It would not be part of the Cape Colony and would be under neither Roman-Dutch law nor English common law.

Peace lasted for only three years, before the eighth frontier war erupted. In I 850 , a time of severe drought, Governor Smith became alarmed at the influence of a young prophet named Mlanjeni, who had set out to purify the country of bewitching materials which he claimed had caused all the ills of the Xhosa. ${ }^{24}$ Sandile was summoned to a meeting to affirm his loyalty, and was deposed as chief when he failed to attend. ${ }^{25}$ Sandile's response was to visit Mlanjeni, and then to order all those who wanted to join his cause to kill one head of cattle, in accordance with the prophet's instructions. ${ }^{26}$ The Xhosa fighters were now doctored for war. In response, Smith issued proclamations to loyal inhabitants to enrol as volunteers. ${ }^{27}$ On 16 December 1850 , he proclaimed Sandile an outlaw, and called a meeting of the Ngqika chiefs, where the severity of his tone convinced many of the chiefs that there would now be war. ${ }^{28}$ After the meeting, Smith sent troops into the Amatola Mountains to flush Sandile out of the country. However, this force was ambushed, and on Christmas Day, three military villages in Victoria were attacked and destroyed by Xhosa fighters. Smith was himself besieged in Fort Cox, unable to break out until 3 I December. He now proclaimed martial law in the frontier districts, and directed all men between the ages of eighteen and fifty to enrol for military service. $\mathrm{He}$ also proclaimed 'all rebel Kafirs [to be] treacherous enemies'. ${ }^{29}$ The rebellion and war which ensued would continue until I 853 .

23 PP I 847-48 (969), enc. I in No. 7, pp. 25-26.

24 PP I85I (I334) XXXVIII. I, enc. 2 in No. 2, p. I 5.

25 He was replaced as chief by Charles Brownlee: PP I 85 I (I334), No. 9, p. 38 ; PP I 85 I (1334), enc. 5 in No. 9, p. 44 .

26 PP I 85 I (I334), p. I05. Jeff Peires explains that it was the dun and yellow cattle whose colour most resembled that of whites - who were to be killed first. Peires, The Dead Will Arise, p. Io.

27 PP I 85 I (I334), enc. 6 in No. I4, p. 62.

${ }^{28}$ PP I 85 I (I334), encs. 3-4 in No. I 5, p. 68; PP I 85 I (635), p. 385.

29 Proclamation dated 25 December I 850 , PP I 85 I (I334), enc. 4 in No. I6, p. 74 . Martial law was proclaimed in Albany, Uitenhage, Somerset, Cradock, Graaff-Reinet, Victoria 
The Ngqika rebels were soon joined by the 'Hottentot' settlers of Kat River. ${ }^{3 \circ}$ In previous confrontations with the Xhosa, these settlers had joined the levies which had gone to battle. By I850, their enthusiasm to assist the British had disappeared, largely because of the high-handed treatment they had hitherto received, being defrauded of promised payment and returning to devastated homes when war was over. At the end of December, the half-Xhosa, half-Khoi leader of the Blinkwater settlement at Kat River, Hermanus Matroos - who had himself fought for the British during the War of the Axe - launched his own attack at Fort Beaufort. He was joined by large numbers of discontented Khoi. ${ }^{3 \mathrm{I}}$ Although acting in concert with Sandile, the Kat River rebellion was perceived to be an assertion of 'Hottentot' identity against the British. It was, moreover, a rebellion against the Queen by a people whose subjecthood was undoubted. ${ }^{32}$ On I I January I85I - six days after Smith had issued a proclamation calling for a war of expulsion against Matroos, the Ngqika and Seyolo $^{33}$ - Matroos launched an attack on Fort Beaufort. Although he was killed at the end of a seven-hour battle, the rebellion continued under the leadership of Willem Uithaalder, who took Fort Armstrong on 22 January, turning it into a rebel citadel. For a month, the rebels remained in that stronghold, until it was recaptured by the colonial forces, with the loss of 27 rebel lives, and with 160 prisoners being taken. ${ }^{34}$ This turned the tide for the rebellion, which had been suppressed by March.

In the meantime, the war against Sandile continued. By the middle of 1852 , the large majority of the Ngqikas had been driven across the Kei. Smith's replacement as Governor, Sir George Cathcart, now decided to take the war across that river to Sarhili, the Gcaleka chief, who was seen to be providing support for the Ngqika (whose

and Albert. There was not much enthusiasm among the Dutch-speaking population to join these forces: PP I85I (I334), No. IO, pp. I25-I26.

30 The community here was made up of people of Khoi descent, as well as those of mixed Khoi-European heritage ('Bastaards') and mixed African descent, who forged an identity as 'Hottentots': see Keegan, Colonial South Africa, pp. II 8-I 2 I; and Ross, The Borders of Race.

${ }^{31}$ Elbourne, Blood Ground, pp. 349-350. ${ }^{32}$ Mostert, Frontiers, p. I082.

33 Seyolo (or Siyolo) was the only Ndlambe chief to join the insurrection. PP I85I (1334), enc. 6 in No. I7, p. 79.

34 PP I 85 I (1352) XXXVIII. I 53, enc. 3 in No. 7, p. 23. 
paramount chief he was). ${ }^{35}$ On I2 August I 852 , colonial troops reached Sarhili's deserted kraal, burning it and capturing 9,800 head of cattle. ${ }^{36}$ Although Sandile, Maqoma and Seyolo all still remained at large, Cathcart was now confident that he had gained complete control over the former Ngqika territory west of the Kei, and that the rebellion had been successfully suppressed by the force of arms. By January I 853 , he was prepared to offer Sarhili pardon and peace, since he was now convinced that he would no longer aid the Ngqika rebels. ${ }^{37}$ He was also soon willing 'to extend the Royal pardon to the late rebels, now sufficiently humbled and subdued'. This was not simply a matter of mercy, but of control; for, in the Governor's view, 'the only way of putting an end to the Gaika rebellion, with a prospect of permanent security, is to pardon the Chief Sandilli', provided he made 'due submission' and 'held himself responsible for his people's conduct'. ${ }^{38}$ Sandile duly made the submission demanded and was pardoned. ${ }^{39} \mathrm{By}$ contrast, Seyolo, who had surrendered on 9 October I 852 , was tried by a martial law court at Grahamstown for rebellion and sedition. He was sentenced to death, though this was commuted by Cathcart to life imprisonment. ${ }^{40}$

The Xhosa chiefs had not been subdued by the eighth frontier war, and the amount of territory they had lost was not great. It would only be four years later, in the aftermath of the great cattlekilling movement in Xhosaland in $1856-1857$, that the power of these chiefs would be undermined. ${ }^{4 \mathrm{I}}$ Another new Governor, Sir George Grey, had the ambition to increase control over the chiefs; and the cattle-killing delusion gave him the perfect opportunity to secure his aims. In an eleven-month period commencing in April I 856, the Xhosa slaughtered 400,000 of their cattle, after a young girl had prophesied that the dead would arise and drive out the Europeans, once the people had destroyed their cattle. The result was catastrophic for the Xhosa,

35 PP I852-53 (I635) LXVI. 395, No. 25, pp. I 24-I 25.

${ }^{6}$ PP I $852-53$ ( I635), enc. in No 29, p. I 44; No. 38 p. I67; cf. PP I 852-53 (I635), enc. in No. 29, p. I45.

37 See PP I 8 52-53 (I635), No. 39, p. I 74; No. 40, pp. I75-I 76; No. 49, p. 2 I 5; No. 5 I, pp. 2I8-22I; No. 52, p. 229; and enc. I in No. 53, p. 23 I.

38 PP I $852-53$ (I635), No. 5 I, p. 2 I 8 at p. 226.

39 PP I852-53 (I635), No. 54, p. 232; and Galbraith, Reluctant Empire, p. 264.

40 PP I852-3 (I635), No. 44, p. I9I at pp. I93, I97.

4I See Peires, The Dead Will Arise; and Price, Making Empire, pp. 267-334. 
40,000 of whom died of starvation. It also gave the colonial authorities a pretext to move against several chiefs (including Phato, Mhala ${ }^{42}$ and Maqoma) by contending that the killings were not the result of superstition but were part of 'a plot for involving the country in war, and for the entire expulsion of the European race from ... the Frontier districts'. Although Maqoma was acquitted in November I857 of inciting the murder of an informer by a summary court, he was convicted of receiving stolen cattle, and sentenced to twenty years' imprisonment for it. ${ }^{43}$

The next - the ninth and last - frontier war, known as the 'war of Ngcayecibi', broke out in I877. After the cattle-killing of 1857 , the Gcalekas were driven across the Mbashe River, but were subsequently allowed to resettle west of that river. There, they were ruled by Sarhili in a state of semi-independence, with a British Resident present. However, their ancestral lands were now occupied by the Mfengu, a matter which caused considerable resentment among the Gcaleka, and it was a clash between these groups which led to war. Although Sarhili wanted a truce with the British, he was unable to restrain his more warlike followers from continuing to fight the Mfengu. In response, imperial troops aided by colonial volunteers and Mfengus destroyed Sarhili's kraal and drove the Gcalekas over the Mbashe. The Governor of the Cape, Sir Bartle Frere, now decided that there was no alternative but to annex Sarhili's country and to depose the chief. ${ }^{44}$ Although it appeared by the middle of November that Sarhili's forces had been broken up and driven out of Galekaland, ${ }^{45}$ the war soon entered a second phase, when the Ngqika within the colony joined in rebellion. ${ }^{46}$ After several farms and shops had been burned, and

${ }^{42}$ Mhala had stayed out of the wars but was considered by the British to be one of the most dangerous chiefs in Kaffraria.

43 'Proceedings and Findings of the Court which sat at Fort Hare on the 17 th November I 857', W[estern] C[ape] A[rchives] CCP I/2/I/5:G4. Although he was acquitted of inciting the murder, High Commissioner Grey concluded that Maqoma was 'morally responsible' for the murder 'committed by persons acting under his orders'.

${ }^{44}$ CO $879 /$ I 2/3, No. 9I, p. 2I 4, enclosing the proclamation of 5 October. All residents would thereby become British subjects: CO $879 / \mathrm{I} 2 / 3$, enc. 2 in No. I49, p. 300.

${ }_{45} \mathrm{CO} 879 / \mathrm{I} 2 / 3$, No. I39, p. 293. A summary of events can be found in CO 879/1 2/8, No. Io, p. 8. 'Galekaland' refers to the territory between the Kei and Mbashe rivers.

${ }^{46}$ British Kaffraria had been incorporated into the Cape Colony in I 866 (as will be discussed later in this chapter). 


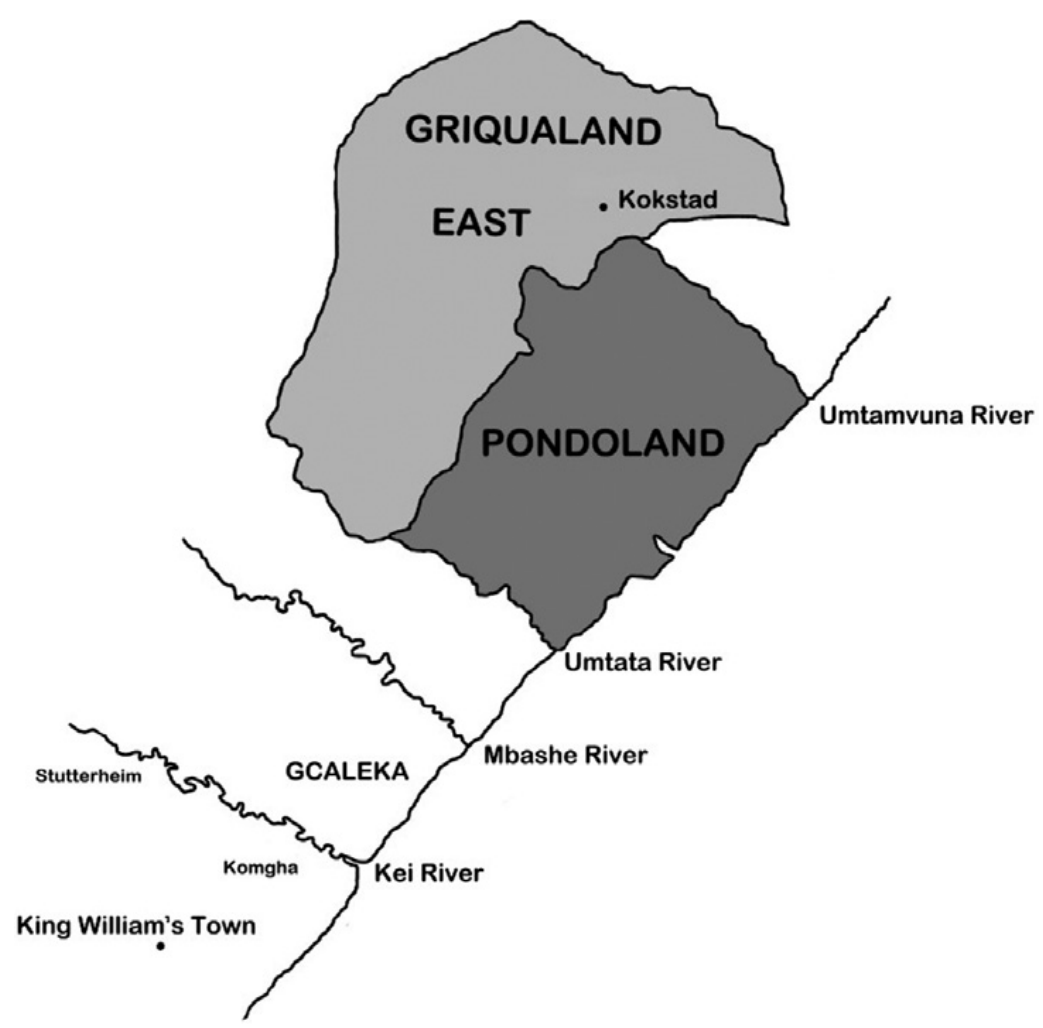

MAP 2 Transkei, Pondoland and Griqualand East

armed bands attempted to block the road to the Transkei, on 3I December I 877 Frere proclaimed martial law in the districts of Stutterheim and Komgha. ${ }^{47}$

In dealing with this outbreak, a conflict soon emerged between Frere and his ministers at the Cape, which had enjoyed responsible government since I 872, over control of the campaign. The Cape Prime Minister, J. C. Molteno, felt that suppression of the Ngqika revolt should be left to colonial forces under ministerial control, while imperial troops should deal with the revolt in Transkei. ${ }^{4}$ Frere, who considered it 'entirely unconstitutional and illegal' to have two independent military authorities under different command in the

47 PP I 878 (c. 2000) LV. 735, No. 79, p. II2. ${ }^{48}$ PP I 878 (c. 2079) LVI. I, pp. I 84, I 86 . 
same area, dismissed both the suggestion and the ministry. ${ }^{49}$ With a new ministry in place under Sir Gordon Sprigg, martial law was lifted on 25 February I $878 . .^{\circ}$ By this point, the Gcaleka had been defeated, while the Ngqika rebels had retreated to the Amatola mountains, where fighting would continue until May. On 20 May i 878, Sandile, who had taken refuge in the mountains, was surrounded by Mfengus, and died during the subsequent exchange of gunfire. Seyolo was already dead.

At the same time that the ninth frontier war was raging, the authorities in the Eastern Cape faced another revolt in Griqualand East, lying north of Pondoland. This territory - also known as 'Nomansland' - had been settled by 2,000 Griquas, who had migrated in I86I-I862 from their settlement at Philippolis. ${ }^{5 \mathrm{I}}$ They had been ceded land by African chiefs, whose rights over it had been reserved in a treaty between the British and the Mpondo ruler Faku in I844. Although Governor Grey refused to assent to their relocation unless they came as British subjects, his successors had treated them as if they were independent. ${ }^{52}$ In this new home, they were governed according to their own constitution and laws by a Kaptyn - Adam Kok - and in I 872 had built a new capital, Kokstad. By this time, the Cape authorities were taking a greater interest in the Griquas, given their concern to ensure stability in the Transkei borderlands. They were particularly worried about what would happen if the elderly Adam Kok were to die with no clear successor in place. A select committee on native affairs was appointed at the Cape, which not only reported that the Griquas had not made 'any progress whatever in civilization' since their move from Philippolis, but also expressed the view that a majority of the inhabitants were 'extremely anxious to be taken at once under British rule'. ${ }^{53}$

Without bothering to consult Adam Kok, the British decided to take greater control in the area. Arriving in Kokstad in October I874,

49 PP I 878 (c. 2079), pp. I9I, 200-203, 2 I 4.

50 PP I 878 (c. 2100) LVI. 255, No. I I, p. I7.

${ }^{5}$ For the background, see Robert Ross, Adam Kok's Griquas: A Study in the Development of Stratification in South Africa (Cambridge, Cambridge University Press, I976), ch. 7 .

52 Minute of Attorney General Thomas Upington, 3 March I 879, CO 48/489/6 I 59; CO $879 / 7 / 16$, No. 53, p. I36.

53 Report of the Select Committee on Native Affairs (Cape Town, I874), CPP A.I 2-'73, pp. III-II3. 
Governor Sir Henry Barkly announced that the government would henceforth be conducted under the instructions of a British Resident. ${ }^{54}$ While nothing more formal was done to signal the commencement of British control, the British began to assume governmental functions, including exercising magisterial jurisdiction and appointing a commission to investigate land claims. ${ }^{55}$ After Adam Kok's death in December I 875, tensions began to escalate between the British and the Griquas, who were increasingly resentful about their treatment by the high-handed Resident, Capt. Matthew Blyth. In I 876, the decision was taken to annex Griqualand East; but, although the necessary legislation was passed in I 877 and letters patent drawn up, the annexation was not implemented until I $879 .^{56}$

The rebellion which erupted in April I 878 was a reaction to the stern treatment of the Griquas by Blyth. Among the leaders of the rebellion were Adam 'Muis' Kok (a nephew of Adam Kok), his brother Lodewyk and Smith Pommer, who had been one of the Kat River rebels in I $85 \mathrm{I}$. A few months before the revolt erupted, Lodewyk had returned from the diamond fields of Griqualand West (which had been annexed to the crown in I872), and had taunted his fellow Griquas for being so supine in surrendering their country. There were reports of Adam Muis, Lodewyk and Adam Kok's widow visiting neighbouring African areas and inciting rebellion among the Basutos, Mpondos and others. ${ }^{57}$ In February i 878, Lodewyk was arrested after an argument with a white trader in Kokstad, during which - the worse for drink - he had threatened to shoot the owner and all Englishmen. Blyth, fearing that a general rising might erupt at any moment, summoned the brothers, who were charged with sedition. After a twoday trial in the following week, Lodewyk was sentenced to six months'

${ }^{54}$ Ross, Adam Kok's Griquas, p. I27. For a description of the meeting, see CO 879/8/ Io, No. 5 , p. 94 .

55 Report of a Commission Appointed by His Excellency the Governor to Inquire into the Affairs of the Territory of Griqualand East (Cape Town, I876), CPP G.37-'76.

${ }^{56}$ Griqualand East Annexation Act, No. 38 of 1877 . The Act was promulgated in I 879, when Griqualand East was incorporated into the Cape Colony.

57 PP I $878-1879$ (c. 2220) LII. I, No. 4I, p. I 26. The (unprinted) enclosures to this despatch are in $\mathrm{CO}_{48 / 486 / 1}{ }_{782}$. See also Papers Relating to the Rebellion in Griqualand East (Cape Town, I878), CPP A.5 I-'78. For an excellent narrative of the events, see Brett Cohen, "'Something Like a Blowing Wind": African Conspiracy and Co-ordination of Resistance to Colonial Rule in South Africa, I 876-I882', PhD Dissertation, Michigan State University, 2000, pp. 203-23. 
imprisonment. Adam Muis fled to Pondoland before his trial. ${ }^{58} \mathrm{He}$ was well received both by the Mpondo chief Mhlangazo ${ }^{59}$ and by his paramount chief Mqikela, whose attitude towards the British had hardened since the Gcaleka outbreak, and who sensed an opportunity to strengthen his position by joining a Griqua revolt.

Muis was joined in Pondoland by more disaffected Griquas, including Smith Pommer, who had been seeking the help of the Hlangweni chief Sidoi. Muis was also relying on help from the Mpondo chiefs, particularly Mqikela, who had received a request from Blyth to return the fugitive. ${ }^{60}$ Mqikela's plan was to send the Griquas out of his territory under an armed escort, ostensibly to hand them over to Blyth, but in reality to join in the attack. ${ }^{61}$ On Thursday, I I April I878, Muis and Smith Pommer entered Griqualand East with a ninety-four-man Mpondo escort. After taking a white farmer prisoner and robbing his farm, ${ }^{62}$ the combined Griqua and Mpondo forces, numbering some 200, headed for the Old Laager, about three miles outside Kokstad, to prepare their revolt. ${ }^{63}$ They remained there until the following Sunday. In the meantime, Blyth sent numerous messengers to them, asking them to lay down their arms, and requesting the widow of Adam Kok, who was seen to be one of the leaders of the rebellion, to come out from the camp. After a series of prevarications, Blyth gave a half hour ultimatum, at the end of which he launched an attack, in which eighteen men, including Adam Muis, were killed. Most escaped into the Ingeli mountains, where some (including Smith Pommer) were killed, and many more captured.

Blyth attributed the Griqua rebellion to 'the spirit of restlessness and disaffection towards the Government' which was to be found

$5^{8}$ See Blyth's account in CO 48/486/I I782, f. I45.

59 Mhlangazo was angry at the British for demanding that he hand over fugitives accused of committing a murder in Griqualand East: see the report of J. Oxley Oxland, Blue Book on Native Affairs (Cape Town, I879) CPP G.33-'79, pp. I2I-I22, and PP I878-I879 (c. 2308) LIII. 225 , enc. 4 in No. I3, p. 54.

${ }^{60}$ Blyth to Secretary of Native Affairs, 23 April I 878 , CO 48/486/I I 782 , f. 72.

${ }_{61}$ Deposition of Coenrad Wardvogel, CO 48/486/I I 782 , f. 22 I. See also CO 879/I 4/6, No. I28, p. I92 at p. I93. As one British official later observed, the regiment was to 'act as a feeler, and if even a partial success had attended the Griqua outbreak, the whole Pondo army would have been poured into East Griqualand'. Oxley Oxland, Blue Book on Native Affairs, CPP G.33-'79, p. I22.

${ }_{62}$ Blyth to Secretary of Native Affairs, 23 April I 878, CO 48/486/I I 782 , f. 72.

${ }^{63}$ For their warlike aims, see $\mathrm{CO} 48 / 486 /$ I I 782 , ff. 98, $250-25$ I. 
throughout the region at the start of I $878 .{ }^{64} \mathrm{He}$ saw no reason for them to rebel, being blind to their resentment at being taken over and effectively dispossessed of their land. Officials in the Cape and London both blamed Mqikela for encouraging the rising. ${ }^{65}$ Although Blyth was excoriated in the Natal Witness, the Colonial Office commended his conduct. ${ }^{66}$ After the rebellion was crushed, $\mathrm{I} 4 \mathrm{O}$ were taken into custody. Depositions were taken from these prisoners, with admissions elicited from one witness being used to cajole more information from another. Officials in London favoured lenient treatment of the prisoners - other than the ringleaders - not least because many of the followers had been induced to join by threats or deception, and had been captured without arms. With nowhere to hold them in Griqualand East, they were sent first to Durban and then to Cape Town, where they were held (after August) in the Amsterdam Battery.

Over a period of a half-century, the Cape Colony saw repeated wars and emergencies on its eastern frontier. As shall now be seen, 'exceptional' measures were used in these emergencies to deal with rebels and enemies, in areas where the nature of colonial jurisdiction was sometimes questionable. On the frontier, there had always been officials, like Sir Harry Smith, who were keen on asserting power without worrying too much about legal niceties; but the ability of such men to act wholly outside the law was constrained by political and legal voices, both at Cape Town and in London, which called for legal procedures to be observed. The scope for rule-of-law arguments to impinge on executive action was all the greater in the Cape, since it did not resort to ad hominem statutes to detain its own enemies.

\section{The Reach of Martial Law}

Martial law was proclaimed in the Eastern Cape during each of these crises. Such proclamations raised important questions about the status of martial law, particularly if civilian courts remained in operation.

${ }^{64}$ Blyth's affidavit, in In re Willem Kok and Nathaniel Balie, in Eben J. Buchanan, Cases in the Supreme Court of the Cape of Good Hope during the Year I 879 (Cape Town, Juta, I880), p. 45 [Juta Reports, I879, p. 45] at 59.

65 Report of Oxley Oxland, Blue Book on Native Affairs, CPP G. 33-'79, p. I22; minute of Arthur A. Pearson, CO 48/486/I I 782 .

${ }^{66}$ See Minute of Arthur A. Pearson, CO 48/486/I I 782 . 
Although such questions were often raised by officials when martial law courts were used to try rebels, the most important discussion of martial law by a South African court before the Anglo-Boer war came in a case of I85I which had nothing to do with civil liberties. Standen v. Godfrey examined whether the normal processes of debt recovery could be used during martial law, when the debtor might have been called up to defend the frontier and be unable to answer the case. The fact that both martial law and civil law were in operation at this time generated much irritation in the Eastern Cape. According to The Colonist, it put shopkeepers 'in the position of the earthen pot, surrounded by iron pots. On one side they have the Kaffirs; on the other, the law. ${ }^{, 67}$ The matter was referred to the Cape's Attorney General, William Porter - 'as progressive an official as the Cape produced" ${ }^{68}$ - who thought that a proclamation of martial law did not supersede the jurisdiction of the civil courts, though it might justify the acts of the military authorities. ${ }^{69}$ In Porter's view, if the civil courts were closed and all executions of judgments suspended, it might favour mala fide debtors, and undermine credit.

The question then went before Cape Supreme Court, where Porter argued that the civil courts should proceed as if there were no martial law until such point that the Governor put a stop to their judicature. ${ }^{70}$ However, this view did not persuade the Chief Justice, Sir John Wylde, ${ }^{7 \mathrm{I}}$ who held that civil law was dislodged in times of war. In his view, 'under a simple, direct and absolute proclamation of martial

67 The Colonist, 5 July I85I, reprinted in De Zuid-Afrikaan, I7 July I85I, p. 3. Quoting the Duke of Wellington's definition of martial law as the will of the commander, it criticised Sir Harry Smith for failing to set out the rules and regulations according to which his will was to be carried out.

${ }^{68}$ Keegan, Colonial South Africa, p. I 58. See J. L. McCracken, New Light at the Cape of Good Hope: William Porter, the Father of Cape Liberalism (Belfast, Ulster Historical Foundation, 1993).

69 Natal Witness, 25 April I 85 I, p. 6. He suggested that civilian courts allow execution of judgment only where it was just to do so.

${ }^{70}$ His view reflected the $\mathrm{I} 757$ opinion of the law officers that a proclamation of martial law did not suspend the ordinary course of law 'any further than is absolutely necessary, to answer the then military service of the public'. George Chalmers, Opinions of Eminent Lawyers on Various Points of English Jurisprudence, Chiefly Concerning the Colonies, Fisheries, and Commerce, 2 vols. (London, Reed and Hunter, I8 I4), vol. I, p. 267.

${ }^{71}$ For Wylde, see F. St Leger Searle, 'Sir John Wylde', South African Law Journal, vol. 50 (I933), pp. 284-297. He was the brother of Thomas Wilde, who was (as Lord Truro) Lord Chancellor in Palmerston's government between I 850 and I 852 . 
law, the civil judicature was stayed, as the two jurisdictions cannot work concurrently'. Echoing the Duke of Wellington's recent definition, he added that under martial law, judges no longer ministered under the Royal Charter, 'but upon the sufferance and under the will of the commander-in-chief', who had the power to prevent witnesses or jurors from attending court. Indeed, he went so far as to say that it was for the Governor alone to decide on whether the emergency warranted recourse to martial law, and the court would not question it. ${ }^{72}$ Wylde's dictum would later be seized on by those who sought to oust the jurisdiction of civil courts to review the detention of suspects under martial law; but its prime aim was to shield debtors from unexpected executions while they were fighting on the frontier.

Legislators at the Cape remained aware that martial law was a legal anomaly, and that it was necessary to pass indemnity acts once civilian rule was restored. On each occasion, martial law was followed by an indemnity act. ${ }^{73}$ However, the passage of such legislation was not regarded simply as a matter of routine. After martial law was lifted in the Cape in 1836 , legislation was prepared to indemnify the Governor (and those under him) for acts done 'bona fide, in furtherance and in the execution of the objects for which martial law was proclaimed'. ${ }^{74}$ On hearing of this, Secretary of State Glenelg questioned whether the colonial legislature had the authority to indemnify a Governor who was responsible to the king, parliament 'and, in certain cases, to the Court of King's Bench at Westminster, but not to the colonial tribunals'. Glenelg also disapproved of indemnifying all bona fide acts, commenting that many acts of injustice and cruelty might have been done 'bona fide' and that the legislation should have referred to 'all acts necessarily or properly done'. ${ }^{75}$ Despite his qualms, the wording was not changed.

Indemnity legislation could also be controversial. The indemnity ordinance which passed in March I 847 was pushed through because

72 Standen v. Godfrey (I 85I) I Searle 6I at 63. A similar view was taken in Natal, where a landowner from Pietermaritzburg sought an interdict to prevent the levying of a force of Zulus (under martial law proclaimed south of the Umkomaas River on 23 January) to support the troops on the Cape's frontier. D. D. Buchanan v. Theophilus Shepstone, Natal Witness, 2 I March I 8 I, p. 3.

73 Statute Law of the Cape of Good Hope (Cape Town, Saul Solomon \& Co, I862): Ordinance Io of I 836, p. 406 ; Ordinance No. 4 of I 847, p. 822; and Ordinance No. 8 of I 853 , p. I04I; and Military Operations Indemnity Act, No. 23 of I 878.

74 PP I 837 (503), enc. I in No. 2I, p. $52 . \quad{ }^{75}$ PP I 837 (503), No. 22, p. 53 at p. 54. 
of the fear that advantage would be taken of the 'approaching Circuit of one of the Judges of the Supreme Court to institute Suits on a variety of points against the authorities'. ${ }^{76}$ The speed of its passage caused disquiet in the press, for there was much anger over the way that waggon-drivers had been severely disciplined by military commanders, who it was felt needed to be held to account. 'The deep indignation occasioned among all classes of society at the personal injuries inflicted on some of the burghers, by subordinates, and sanctioned by Sir Peregrine Maitland has not abated', wrote De Zuid-Afrikaan in March. ${ }^{77}$ They had in mind the case of a waggon driver named John Crawford Smith, who had refused an order to cut some wood, and had been given twenty-five lashes as punishment, as a result of which the waggon drivers became much more obedient. In fact, the ordinance was drawn up so as not to indemnify those actions which were already the subject of litigation or prosecution in the courts. ${ }^{78}$

During the frontier wars of the 1830 s and 1840 , the primary purpose of declaring martial law was to facilitate the assembling and use of troops to fight the war, rather than to detain or punish. D'Urban's proclamation of martial law in January I 835 was designed to 'embody the inhabitants' of the districts in question to aid His Majesty's forces in repelling the invaders, and applied 'in all matters connected with the assembling and conducting the forces of the colony'. ${ }^{79}$ Smith used martial law powers in Grahamstown to raise troops, and to discipline them - particularly the 'Hottentots', who complained about being kept in the field after white farmers had been allowed to return home, and who were not paid for their service to the Government. ${ }^{80}$ Similarly, in 1846 , Maitland declared martial law to be in force throughout the colony for all matters connected with

${ }^{76}$ Pottinger to Grey, I6 June I 847, WCA GH 23/I7, f. [I08].

77 De Zuid-Afrikaan, 23 March I 847, p. 3.

${ }^{78}$ De Zuid-Afrikaan, 23 March I 847, p. 3. The case of the waggon-driver Smith was taken up by a cleric, Dr Tancred, who raised subscriptions to initiate a prosecution of Lindsay, and an action for assault was eventually brought in Grahamstown on 29 March I 847. Harriet Ward, Five Years in Kaffirland, 2 vols (London, Henry Colburn, I848), ii: $269-274$.

79 PP I $835(252)$ enc. 4 in No. 42 p. I 30.

${ }^{80}$ Mostert, Frontiers, p. 679 . On one occasion, Smith sentenced disobedient troops to 300 lashes and their leader to three months' solitary confinement, telling them, 'Now you see what martial law is; you think you cannot be forced to do anything, but I say you shall serve as long as it pleases His Majesty': PP I 836 (538) VII. I, p. 7 IO. 
assembling and supplying the troops. ${ }^{8 \mathrm{I}}$ Like Smith, he thought these powers were needed to call out and arm the burgher force. He also thought that he had no power to issue the martial law proclamation he considered necessary to raise the troops until the war had actually begun. ${ }^{82}$ By contrast, his successor, Pottinger, did not think it essential to have martial law to raise troops. After Maitland had revoked martial law in January $\mathrm{I} 847$, Pottinger (who felt that the revocation was premature, given the continuing problems on the frontier) opted not to reimpose it (since this might excite 'groundless alarm' and encroach on people's civil rights) but instead issued a proclamation calling for volunteers to aid the regular forces. ${ }^{83}$

\section{Martial Law in Conquered Territories}

Besides being used to raise troops, martial law was also used for a number of other purposes, which raised important legal questions about its nature and relationship with civil law. To begin with, it was used to rule newly conquered territories. This could raise complicated constitutional questions, as can be seen from the debates over Queen Adelaide Province, where martial law was declared on I6 June I 835 . Early in October I835, the senior puisne judge at the Cape, William Menzies, pointed out that this territory had to be regarded as governed by the laws of the Cape and be subject to its Supreme Court, thanks to Governor D'Urban's proclamation of May, which extended the Cape's border to the Kei. This presented potentially serious obstacles in the way of applying the peace treaties signed by D'Urban in September, since their provisions often contradicted Cape law. ${ }^{84}$ As an example, Menzies pointed out that once martial law was lifted, any white settler who killed an African violating the thirteenth article of the treaty - which stated that armed Africans crossing the Keiskamma without a pass could be

8I PP I 847 (786), No. 9, p. I22. A broader martial law was proclaimed in the eastern districts: ibid., No. 8, p. I2I.

82 As he explained, 'My own apprehension is that, according to the principles of the English Government, a resort to such extreme measures is only justifiable when the country is suffering invasion, and its soil is in the occupation of an enemy': PP I 847 (786), No. I6, p. I40 at p. I43.

83 PP I $847-48$ (9I2), No. Io, p. 27 ; enc. 2 in No. I3, p. 4 I.

84 This was especially so of provisions relating to the movement of persons and to the liability of chiefs for depredations. PP I836 (279), enc. 5 in No. 9, p. 95. 
shot - would be liable to be tried for murder. In his view, this problem could only be avoided if the new province were severed from the Colony and treated as a conquered territory and governed under royal prerogative power, until such time as a constitution were granted to it. ${ }^{85}$

When he signed the treaties, D'Urban's intention was to keep martial law in force in the new province 'for a considerable time to come', without applying the laws of the Cape there. As he saw it, martial law would be enforced according to the spirit of the treaties, and could be supplemented and eventually replaced by ordinances 'specially adapted to the condition of these people, still keeping in view the principles of the treaties'. ${ }^{86}$ This aspiration was based on a confused understanding of constitutional law, assuming that the new province could at the same time be treated as part of the Cape Colony, but ruled by a distinct legal order. The matter was referred to Sir John Wylde CJ, who (after consulting the judges) confirmed that the jurisdiction of the Supreme Court extended into the Province of Queen Adelaide. He also pointed to Sir Matthew Hale's opinion that martial law was impermissible in times of peace. ${ }^{87}$ The judges further pointed to the anomaly that although the Supreme Court had jurisdiction (and martial law was ultra vires), no system of circuit courts or magistrates had been created in the province. As a result of these consultations, D'Urban concluded that martial law had to be revoked on I 8 August I 836 , and the jurisdiction of the circuit courts extended for the time being. The lifting of martial law prompted Stockenström and Harry Smith to conclude that the territory could no longer be held, for, as Smith put it, 'the sooner we march out of the province the better, for how am I to eat up a Kaffir according to Blackstone?" ${ }^{88}$ Although he had anticipated more time to reorient British policy in this area,

${ }^{8}$ Menzies also felt that 'it is impossible that all the laws which are necessary for the protection of and due administration of justice to the civilized inhabitants of this colony can be effectually or beneficially made applicable to the Kafirs in their present state'. 'Legal Notes on the Treaty with the Kafirs of the I7th September I835', PP I 85 I (424), p. I 97 at p. I98; cf. Macmillan, Bantu, Boer and Briton, pp. I 52-I 53.

${ }^{86}$ PP I 836 (279), No. 9, p. 86 at p. 89; PP I 837 (503), enc. 2 in No. 3, p. 5.

${ }^{87}$ D’Urban to Stockenström, I9 August I836, WCA LG 56, f. I3; referring to Sir Matthew Hale, History of the Pleas of The Crown, 2 vols. (London, I736), vol. I, p.500; History of the Common Law of England (London, I7I3), pp. 40-4I. See also Galbraith, Reluctant Empire, p. I39.

${ }^{88}$ C. W. Hutton (ed.), The Autobiography of the Late Sir Andries Stockenstrom, Bart., 2 vols. (Cape Town, Juta \& Co, I887), vol. 2, p. 45. 
Lieutenant-Governor Stockenström now hurried to enter into new treaties with the African chiefs and to renounce the Province of Adelaide. In this instance, legal concerns had a direct impact on policy.

The question of how to rule this territory returned in I 846 , when the British took control of 'British Kaffraria'. In order to avoid having a 'Kafir Government under British Protection', Earl Grey wanted to assert British sovereignty over the area. Grey thought that a 'system of military rule' was 'the only one fitted for the circumstances of this country'. He felt this could be introduced either by annexing the territory to the Cape, and passing an ordinance instituting martial law in this area, or by holding it as a 'separate territory acquired by H.M. by right of conquest, and in which therefore military authority alone would be recognised until H.M. by order in council should otherwise direct'. ${ }^{89}$ However, the permanent under-secretary of state, James Stephen, advised against any claim to sovereignty, since he doubted 'the possibility of maintaining, in any part of the Queen's Dominions, such a system of Government as the exigencies of this case seem to demand'. He did not want Kaffraria to be made a separate colony, since 'it must have a separate legislature, and we must take the chance of their legislating wisely or unwisely'. Nor did he favour the idea that it become part of the Cape, but with a martial law regime:

Martial Law is but another name for the suspension of all law - for the arbitrary dominion of mere force. I cannot conceive any Colonial Legislature fitting such a yoke to the necks of their fellow-Colonists. The local newspapers would inveigh, with all their power, against it. The lawyers of the place would set themselves to prove that such legislation was invalid. The judges and the juries would agree with them. Unless the Governor were strong-willed enough to dismiss the judges, and silence the editors, any such law would be defeated as soon as made. If the Governor were strong-willed enough for this purpose, our own newspapers would hold him up as a monster of Colonial oppression [. . . ] nor would there be wanting in the House of Commons the usual amount of successful invective against the tyranny of the Colonial Office and its ministers abroad. $9^{\circ}$

Stephen's objections persuaded the Secretary of State, whose instructions to the new Governor, Pottinger, explained that the

${ }^{89}$ Undated note by Grey, CO 48/264, f. 387 .

90 Memorandum from James Stephen to Lord Grey, 28 September I 846, CO 48/264, f. 4 IO. 
territory should not be annexed either as a new colony or as a part of the Cape Colony, since this would require the introduction either of the English common law or the laws of the Cape, neither of which would be suitable. He rather wanted the tribes 'to acknowledge the Queen as the protector of their nation, and to receive a British officer as the commander in chief of all their national forces'. ${ }^{\text {I }}$ According to this plan, 'British Kaffraria' would be a kind of protectorate, for which the Cape Governor would be responsible, in the capacity of a High Commissioner..$^{22}$

The plan for British Kaffraria was therefore to rule through the chiefs, but under regulations set by the High Commissioner's representative. In practice, this was a system of martial law. ${ }^{93}$ Commissioners would be appointed to reside near the chiefs, to guide them. European traders would have the status of 'camp followers', subject to martial law for petty offences; and subject to the Cape colony's extraterritorial jurisdiction for more serious ones. ${ }^{94}$ In March I 849, Attorney General Porter wrote an opinion on the legal status of this new colony. In his view, it was a conquered country held by military occupation, awaiting the issue by the crown of the formal instructions which would turn it into a colony. There was no time limit for this transitory state. In Porter's view, this kind of regime suited the people of the country. "The "word" of the great chief sent from the colony is the law the Kafirs look to, and the only law they understand,' he argued, 'With them the Governor is the Government."95

Although Letters Patent were issued by the crown in I850, authorising the Governor of the Cape to set up an executive council and judicial system for the new territories, they were not published for another decade. ${ }^{96}$ Only after 1860 were steps taken to introduce a regular system of judicature in this area, which was finally incorporated into the Cape in I866. In the intervening period, the

9I PP I 847-48 (9I2), No. I, at p. 3.

92 For Pottinger's plan, see PP I 847-48 (912), enc. I in No. I9, p. 73.

93 Macmillan, Bantu, Boer and Briton, p. 30I. 94 PP I $847-48$ (969), No. 3, p. 26.

$95 \mathrm{CO} 879 / \mathrm{I} / \mathrm{I}$, enc. 2 in No. 3, p. Io at p. 20.

96 British Kaffraria: The People's Blue Book Containing the True and Full Account of the Political Commotion in British Kaffraria (King William's Town, S. E. Bowles, I863), pp. I2-I4; and Peires, The Dead Will Arise, p. 283. See also Grey's explanation to Labouchere for the delay in his despatch of 8 December I $857, \mathrm{CO}_{48 / 3} 85 /$ I 269 , f. I38. 
territory was ruled under martial law; though as increasing numbers of settlers were introduced into the new colony, magistrates were appointed who dealt with some civil disputes and crimes, and a special criminal court was created in 1857 to deal with serious crimes. ${ }^{97}$ British Kaffraria in effect operated in a kind of constitutional void, with the system of martial law imposed on this conquered territory not being subject to supervision either by the Cape courts or the highest court in the empire, the Privy Council.

Even here, however, the legal conscience of Cape officials could act as a limited restraint on executive action. After the Xhosa chiefs, Phato and Mhala, had been tried in the aftermath of the cattle killings in I 858 , their cases were sent to William Porter for his opinion, before Grey confirmed the sentences. The men had been tried under the same summary procedure which had been used against Maqoma. ${ }^{98}$ Both were convicted for receiving stolen cattle, while Mhala was also convicted of devising war against the Queen. Porter had severe reservations about both cases. He was troubled by the fact that, in Phato's case, a second trial had been ordered by chief commissioner Maclean after evidence was introduced at the first trial which showed that he had not known that the cattle were stolen. ${ }^{99}$ Although Grey responded that in the unsettled state of Kaffraria, Africans could not 'claim every technical advantage which would be awarded to a British subject in a regularly constituted Court', ${ }^{\text {10o }}$ he sentenced Phato only to five years' transportation to Cape Town, where he would be allowed to remain 'comfortably taken care of' in the hospital. Porter was also critical of the proceedings against Mhala, pointing out that the

97 For a study of its administration see Denver A. Webb, 'More Than Just a Public Execution: Martial Law, Crime and the Nature of Colonial Power in British Kaffraria', South African Historical Journal, vol. 65:2 (20I3), pp. 293-3 I6.

${ }^{98}$ According to the Attorney General of British Kaffraria, Henry Barrington, it was expedient in these cases 'to omit the forms usual among the civilized people of Europe in criminal cases ... and to proceed in the simplest and most natural manner'. Memorandum 30 April I 857 , WCA BK I4. The trials were presided over by special magistrates, sitting with military officers.

99 As Porter explained, 'the expediency of maintaining inviolated [sic] the independence of Courts Martial, trying Kafirs, and of proving to Kafirs that these Courts are really independent, is very great, and many repetitions of what has taken place in this case would go far to turn Courts Martial into a farce'. Memorandum dated I 7 March I 858, WCA GH 8/34, f. Iо03. See also Peires, The Dead Will Arise, p. 23 I.

I00 WCA GH 8/34, ff. I038-1039. 
evidence would not have been sufficient to persuade a Cape jury to convict. ${ }^{\text {IOI }}$ Porter's own view of the evidence was that 'fanaticism had more to do with the suicidal movement' of the cattle killing than conspiracy. He also thought that the treason charges brought against Mhala - under the British Treason Felony Act of I 848 - could not be sustained, since (even if the Act applied in Kaffraria, which he doubted) it was nowhere alleged that he was a subject owing allegiance to the crown. Although Porter conceded that, in the current conditions, the removal 'of such a wily and influential chief' might have been necessary for 'the welfare of all classes in Kafirland', he added that 'I would prefer to rest his detention in this Colony upon considerations of this sort, than upon a conviction under an inapplicable statute, supported by what strikes me as somewhat defective evidence.' ${ }^{\text {IO2 }}$ In response, Mhala's sentence was reduced from transportation for life to five years' imprisonment, with a provision for its remission 'if it should subsequently be thought that the Attorney-General is right and I am wrong'. ${ }^{103}$ These trials had been intended to prove that the great cattlekilling had been a plot hatched by the Xhosa chiefs, a manipulation of law and its forms as a form of lawfare against those who stood in the way of imperial expansion. While the conscience of the Cape's Attorney General did not secure these chiefs their liberty, it was enough to draw something of the sting of Grey's lawfare.

\section{Martial Law Trials}

Martial law was not generally used in the earlier wars in the Cape against non-subject Africans to detain them or try them as rebels. Thus, when revoking martial law in January I 847 , Maitland informed Grey that the 'few Kafir prisoners of war detained in the colony have been passed over the Keiskamma and dismissed' ${ }^{\text {I04 }}$ Pottinger also regarded those who were taken in arms during the campaign against Sandile as 'prisoners of war' to be disarmed and released. ${ }^{105}$ However, from the I 85 os, martial law courts were used on a number of occasions to try

\footnotetext{
го WCA GH 8/36, Opinion dated 4 November I 858 , f. 337.

ro2 WCA GH 8/36, Opinion dated 6 November I 858, f. 379.

${ }^{103}$ Quoted in Peires, The Dead will Arise, p. 236.

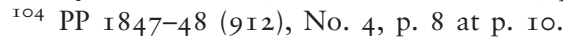

I05 PP I $847-48$ (9I2), No. 37, p. I37 at p. I4I.
} 
rebel subjects. This raised the question of the status of martial law courts when civilian courts were open, and of the validity of the sentences of these courts once martial law was lifted.

In the aftermath of the Kat River rebellion, when Governor Smith determined to try the captured rebels, he consulted his Attorney General on which tribunal to use. ${ }^{106}$ Porter thought it best to use martial law courts, since it would be 'unusual' to send rebels to a civilian tribunal 'in the midst of actual hostilities and during the existence of martial law'. He was also aware that Justice William Musgrave - the judge who was due to take the next circuit - had qualms about holding a civil court when martial law remained in place. In addition, Porter pointed out that in September 1848 , in Bloemfontein, Smith had himself ordered the execution under martial law of the burgher Thomas Dreyer, after Andries Pretorius's Boer Rebellion at Boomplaats. ${ }^{107}$ Since Dreyer might have been given a civilian trial under the Cape's extraterritorial jurisdiction, ${ }^{\text {I08 }}$ he argued that for the British now to give 'Hottentots' the kind of trial they had denied Boers would only cause resentment. Smith agreed with this advice, which would have the advantage of imposing speedy punishment. ${ }^{\text {109 }}$ The Colonial Office took a more cautious approach. Mindful of the recent parliamentary debates over martial law in Ceylon, Secretary of State Grey pointed out that the sentences of martial law tribunals had no validity unless sanctioned by legislation. While it was the practice to pass indemnity acts to protect soldiers who had inflicted punishments in times of emergency, they did not validate continuing sentences of transportation or imprisonment. For such purposes, an ordinance would be needed to confer powers on martial law courts to try and punish offenders. ${ }^{\text {IIO }}$

${ }^{106}$ Smith's initial intention was to try the more prominent rebel leaders in a civilian tribunal, in part because he did not feel he could spare the officers needed for the military tribunals. PP I 85 I (424), No. I, p. I at p. 3; PP I 852 (I 428 ), enc. in No. 6, p. 36 at p. 37 .

${ }_{107}$ PP I 849 (1059) XXXVI. 433, No. I4, p. 57. For the battle, see Tim Couzens, Battles of South Africa (Claremont, David Philip, 2004).

Io8 $6 \& 7$ William IV c. 57 (I 836), which gave the Cape extraterritorial jurisdiction over British subjects south of the $25^{\text {th }}$ degree of southern latitude.

ro9 3 I March I8 5 I, PP I8 52 (I428), enc. in No. 6, pp. 36-37; PP I85 I (424), No. 3 , p. II at pp. I $2-\mathrm{I} 3$.

iro $\mathrm{CO} 879 / \mathrm{I} / 8$, No. I, p. I. 
In the meantime, local white settler opinion began to call for a judicial commission of inquiry into the rebellion and for the judges to try the rebels. ${ }^{\mathrm{II}}$ This was not out of sympathy for the rebels, since the settlers were of the view that the government's stance towards them had been too lenient. One newspaper was horrified that Smith had given many of the rebels passes allowing them to return home, and recruited others into the military: it argued that the ringleaders should have been summarily executed, and the rest put to labour on public works. ${ }^{\text {II }}$ Those who urged a judicial commission felt that martial law trials entailed 'nothing less than the throwing open a wide door for the escape of delinquents'. ${ }^{\mathrm{II} 3}$ However, the Executive Council of the Cape rejected the proposal to have civilian trials before men who were also being asked to investigate the rebellion. It took the view that there was not very much difference between civilian trials and trials in military courts, save that the former had juries and were constituted according to the Charter of Justice. ${ }^{\mathrm{II}} 4$

Martial law trials consequently proceeded, albeit without the empowering ordinance Grey had in mind. Fifty-four prisoners were tried by a martial law court, which sat between 18 March and 30 April I 85 I. Of these, forty-seven were sentenced to death, three were sentenced to terms of transportation, and the rest acquitted. With one exception, Smith reported, the men were all 'persons of the lowest class ... the tools of more intelligent men whom I have failed to arrest'. The one exception, captured at Fort Beaufort when Hermanus Matroos was killed, was the son of Andries Botha, the Field Cornet of Buxton, who had in the past assisted the British in fighting the Xhosa, and who had himself sought to dissuade the Khoi youth from rebelling. ${ }^{\text {I } 5}$ Andries Botha was himself also arrested, for the colonial authorities were convinced that he had plotted the rebel outbreak with

II Graham's Town Journal, 22 March I 85 I, p. 3.

${ }^{112}$ Cape Frontier Times, 8 April I85I, reprinted in De Zuid-Afrikaan, I7 April i 85 I, p. 6.

${ }^{113}$ Graham's Town Journal, 3 May I 85 I, p. 2.

${ }^{114}$ PP I8 52 (I428), enc. in No. 6, at p. 38 . The Attorney General himself favoured sending brigands who had taken advantage of the revolt to commit robberies and murders for trial by martial law courts, rather than holding them for civilian trials, but the military were not keen to try them: Attorney General to Clerk of the Peace, Albany, 3 May, I 2 June I 85 I, WCA AG 205 I, ff. 58, 94.

${ }^{115}$ PP I 852 (I428), No. IO, p. 72. 
Sandile. He was sent to Cape Town, where he was tried and convicted for treason in 'the first of South Africa's show trials'. ${ }^{\text {II } 6}$

Reviewing the sentences of the martial law prisoners, the Executive Council decided that the death penalty should not be carried out in any of the cases referred to them. Although the council was satisfied that the men were British subjects guilty of levying war against the Queen, and that neither the trials nor the sentences were unlawful, it was considered impolitic to execute them, given that so many other captured rebels had been dismissed with passes, with many subsequently being enrolled by the military to fight the Xhosa. In terms of personal criminality, no distinction could be drawn between those who had been tried and those who had not: it therefore seemed quite random to impose the death penalty on these men. Given the delay which had elapsed, there was also concern that executions would serve not to check insurrection, but to further discontent. In the view of the council, the death penalty should be reserved for three classes of rebels: the ringleaders, those who had been particularly bloodthirsty or malicious, and those who had deserted in the field from the military. ${ }^{\mathrm{II} 7}$

After the council recommended that sentences of life imprisonment with hard labour be imposed, Smith asked the Attorney General whether he had the power to impose such a penalty. Porter replied that colonial legal opinion was divided on the question of martial law. Some felt that the Governor's proclamation instigated it de jure, and that it was within the executive's power to establish martial law with no additional legislative sanction. Others, including himself, felt that an act of indemnity would be needed to justify any act (including imprisonment) which had no other legal sanction bar the Governor's proclamation. He added that difficulties would arise if the prisoners were moved out of the area in which martial law had been proclaimed, since courts in those areas might not recognise its validity. Although members of the council realised that it would be necessary to pass legislation to give legal cover to sentences which for practical reasons needed to be served in the Western Cape, they were in no rush to pass it. They well understood how unlikely it was that any attempt would be

\footnotetext{
${ }^{116}$ Ross, Borders of Race, p. 277; Trial of Andries Botha (Cape Town, Saul Solomon \& Co., I 852 ). His death sentence was commuted to life imprisonment, and he was released in 1855 .

${ }^{117}$ PP I 852 (I 428 ), enc. 3 in No. Io, p. 74.
} 
made to challenge the imprisonment of those convicted under martial law, given both the leniency with which they had been treated and the fact they could be tried again for treason if released. ${ }^{\text {I } 18}$ Eventually legislation was passed in November to legalise the continued detention of those who had been tried by the martial law courts, and to validate any future sentences by these courts. ${ }^{\text {II }}$ The Kat River prisoners did not remain long in gaol. By I 858 , none of the I 23 convicted rebels and their widows who applied for the restoration of their land were still in gaol. ${ }^{\mathrm{I} 20}$ However, they were not the only ones to be tried in martial law courts: among those tried in this way at Grahamstown was Seyolo, who was charged with rebellion and sedition and for waging war against the Queen. He was sentenced to death, but this was commuted by Cathcart to life imprisonment. ${ }^{\mathrm{I} 2 \mathrm{I}}$

The question of trying rebels by martial law courts was raised again in the ninth frontier war. Martial law was proclaimed at the end of I 877 only when the Ngqika - who lived under the crown's jurisdiction in the Cape - joined in rebellion. Governor Frere did not want to proclaim martial law, since he 'did not contemplate suspension of ordinary law courts for ordinary offences'. ${ }^{\mathrm{I} 22}$ Indeed, he suggested that a special session of the High Court might be arranged for the trial of offences against the state. ${ }^{\mathrm{I} 23}$ However, the Cape's ministry preferred a declaration of martial law following the precedents of previous frontier wars, and they were advised by Attorney General Andries Stockenström that, if time was of the essence, then drumhead courts-martial should be used, with an Indemnity Act to follow. ${ }^{\text {I24 }}$ Although Frere soon conceded that martial law would have to be

${ }_{11} 8$ May i 85 I, PP I 852 (I428), enc. 3 in No. Iо, pp. 78 ff.

${ }^{119}$ De Zuid-Afrikaan, I7 November I8 5 I, p. 3. Ordinance No. 4 of I8 5 I, in Statute Law of the Cape of Good Hope (Cape Town, I862) p. 9I 5.

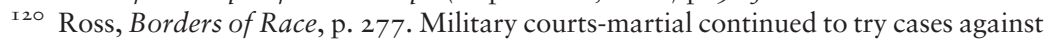
Khoi who had joined the military levies or were in the Cape Mounted Rifles, who were accused of spreading disaffection. Corporal Caspar Sneyman, of the Kat River Levy was sentenced to seven years' transportation for spreading false reports: $D e$ Zuid-Afrikaan, 29 November I 85 I, p. 3.

${ }^{\text {I2I }}$ PP I $852-53$ (I635), No. 44, p. I9I at pp. I93, I97.

${ }^{122}$ PP I878 (c. 2079), enc. in No. 86, p. 220. He initially proposed instead a proclamation authorising the military to assist the police: PP I 878 (c. 2079), p. 218.

${ }^{123}$ PP I 878 (c. 2079), enc. in No. 86, p. 222 at p. 223.

${ }^{\mathrm{I} 24}$ PP I 878 (c. 2079), enc. in No. 86, p. 22I. 
proclaimed, ${ }^{\mathrm{I} 25}$ he thought that rebels could be given fair trials in well-constituted martial courts. The model he had in mind was that of the tribunals set up in India after the Mutiny of $1857 .{ }^{126} \mathrm{On}$ I January I 878 , he appointed five special commissioners to conduct the trial of rebels taken in the field, with one commissioner accompanying every military column. The commissioners were to have the powers of a circuit court, and could impose the death sentence (subject to confirmation by the government). They were to be instructed to ensure 'that all the essentials of a fair trial are secured', with specific charges and clearly stated evidence. ${ }^{127}$ Frere's aim was to make hearings under martial law approximate as closely as possible to the legalism of a civilian trial.

When he saw these provisions, Prime Minister Molteno protested that the 'cumbrous machinery' it created would 'entirely frustrate the object which we had in view in proclaiming martial law'. In his view, all rebels taken in arms should be tried by drumhead courts-martial and shot without delay, while those who laid down their arms should be sentenced to death after summary trials by the commissioners, these sentences being subject to the Governor's approval. ${ }^{128}$ However, Frere was concerned to avoid the kinds of trials which had caused so much controversy in Jamaica, and condemned drumhead courts as being little better than lynch law. ${ }^{\mathrm{I} 29}$ Molteno modified his views after his Attorney General clarified his advice, having studied Cockburn CJ's change in the Jamaican case of Nelson and Brand. ${ }^{\mathrm{I} 30}$ The purpose of drumhead trials, Stockenström now explained, was simply to allow

${ }^{125}$ PP I 878 (c. 2000), No. 79, p. I I 2. Frere felt that the colony's law regarding public order was 'extremely defective', not least because of the constant resort to martial law at times of unrest: the major defect was that the only legislation permitting disarmament was an I 837 Ordinance which applied only to 'foreigners' entering the colony: since the Ngqikas were British subjects, they might lawfully resist attempts to disarm them.

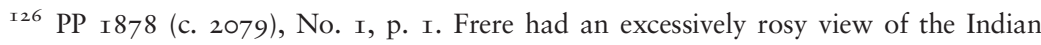
commissioners (who had been appointed under statute): see Rudrangshu Mukherjee, 'The Kanpur Massacres in India in the Revolt of I857: Reply', Past and Present, No. I42 (I994), pp. I80-I 8 I; and Chapter I.

${ }^{127}$ PP I878 (c. 2079), enc. in No. 86, pp. 219-220.

${ }^{\mathrm{I}} 28$ PP I 878 (c. 2079), enc. in No. 86, p. $22 \mathrm{I}$.

${ }_{129} \mathrm{CO} 879 / \mathrm{I} 2 / 8$, enc. I 2 in No. I 20, p. 263 ; PP I 878 (c. 2079), enc. in No. 86, p. 22 I at p. 222.

${ }^{130}$ CO 879/1 $3 /$ I, No. 6, p. I 5 . See also PP I 878 (c. 2144) LVI. 373, enc. 2 in No. 69, p. 125 . 
officers in the field to distinguish between captured rebels - who could justifiably be killed on the field of battle - and 'other enemies', who could not. If men were removed from the battlefield for trial by the commissioners, their execution after such trial would be illegal and would require an indemnity, which might be hard to obtain if they could have been tried in ordinary courts. ${ }^{\mathrm{I} 3 \mathrm{I}}$ For his part, Frere was unconvinced by Stockenström's view of the powers of drumhead courts-martial, ${ }^{\mathrm{I} 2}$ and was sceptical that the Cape assembly would refuse an indemnity, given that his initial suggestion of using the High Court had been rejected by his ministers, and that a tribunal with a legalistic format had been put in place. ${ }^{\mathrm{I} 33}$ The Secretary of State, Sir Michael Hicks Beach (who had already sent Frere copies of the I 867 Circular Dispatches to help guide him), ${ }^{\mathrm{I}}{ }^{4}$ similarly assumed that, if the trials were to be by special commissioners conducting fair hearings, there would be no difficulty in obtaining an Indemnity Act. ${ }^{\mathrm{I} 35}$ Officials in London also frowned on Molteno's desire 'for vigorous measures ... in the form of entrusting excited young officers \& civilians to administer Lynch law'. ${ }^{\text {I36 }}$

In the event, martial law did not remain in place for very long after the dismissal of the ministry at the start of February. Soon after assuming office, the new Attorney General, Thomas Upington, reviewed the topic. ${ }^{\text {I37 }}$ In his view, martial law 'strictly comes within the scope of military jurisdiction', and only 'courts martial properly constituted' could be seen as the kind of 'clearly legal tribunals' which could impose punishments under it. It was therefore necessary to withdraw the powers which had been conferred on the civilian special commissioners. At the same time, he noted that, if the special

${ }^{\text {I3 }}$ Stockenström also now thought that sentences pronounced by Frere's proposed special commissioners could be challenged by habeas corpus applications. PP I 878 (c. 2079), enc. I in No. 86, pp. 222, 223.

${ }^{132} \mathrm{CO} 879 / \mathrm{I} 3 / 2$, enc. 5 in No. 33 , p. 48 at p. 49.

${ }^{133}$ PP I 878 (c. 2079), enc. in No. 86, p. 222-223. He also doubted the practicality of attempting to distinguish between rebels and enemies in the field.

${ }^{134}$ PP I878 (c. 2079), No. I3, p. 2I. Given that the Cape was now a colony with responsible government, officials doubted whether the circulars applied: $\mathrm{CO} 48 / 485 /$ I 442.

${ }^{135} \mathrm{CO} 879 /$ I3/I, No. 5 O, p. 78.

${ }^{136}$ Minute dated I3 February I 878 , CO $48 / 485 /$ I 783 , f. 42.

${ }^{1} 37 \mathrm{CO} 879 / 13 / 2$, enc. 3 in No. 33 , p. 47 at p. 48 ; and PP 1878 (c. 2079), enc. I in No. 86, p. 225 . 
commissioners' powers were revoked, martial law would become a dead letter, since the prisoners had by now all been lodged in ordinary prisons awaiting trial by them. In this situation, there was no reason not to try them now in ordinary courts. On 25 February I 878, the appointment of the five special commissioners was duly cancelled and martial law lifted. ${ }^{\mathrm{I} 38}$ In all, fifty-two people had been tried by the commissioners, of whom thirty-six had been convicted. The longest sentence was one of twenty-one years' imprisonment with hard labour for aiding and abetting murder. Twenty-one others had been convicted of sedition, two of whom had been sentenced to ten years' imprisonment with hard labour. ${ }^{\mathrm{I} 39}$

Officials in London were pleased that martial law had been 'practically a dead letter while it lasted'.$^{140}$ However, they wanted to establish which was the correct view of martial law - Stockenström's, Upington's or Frere's - a matter which was also debated both in the Cape parliament and in the Westminster parliament. ${ }^{\text {III }}$ Edward Fairfield, barrister and clerk in the Colonial Office, felt that Upington's views were sound. Pointing out that the I 867 instructions contemplated that martial law should be administered only by the military, he was concerned that five civilian commissioners had been appointed. He was also concerned that they had imposed sentences of transportation beyond the colony, which even the most regular tribunal had no power to enforce. Assistant under-secretary of state W. R. Malcolm was also troubled by Stockenström's idea that the commander in the field could sift rebels from alien enemies and then kill them in cold blood, which seemed to confuse a right to kill in the heat of battle with a right to execute after the battle was over. ${ }^{\mathrm{I} 2}{ }^{2}$ It was decided to ask the Law Officers for their opinion on which was the better view of martial law. They were also asked about the effect on any sentences of the ending of martial law, and whether an indemnity act would be needed. ${ }^{\mathrm{I} 3}$ The

${ }_{138}$ PP I 878 (c. 2100), No. II, p. I7. ${ }^{139}$ CO 48/486/I4675; WCA AG 97, ff. 208 et seq.

${ }^{140}$ Minute by Edward Fairfield, Io April I 878, CO 48/485/4039.

${ }^{\text {I4I }}$ PP I 878 (c. 2I44) LVI.373, No. 69, p. I I 7; Parl. Debs., third ser., vol. 24I, col. I 26 (24 June I 878).

${ }^{142}$ As he put it, 'A preliminary sifting of the prisoners such as is suggested at once shows that no such over powering necessity exists, $\&$ that the slaughter is not for self preservation but for some quasi-judicial or deterrent object - in other words it would be a massacre.' Minute dated II April I $878, \mathrm{CO}_{4} 8 / 485 / 4039$.

${ }^{143} \mathrm{CO} 879 / 13 / 5$, No. I6, p. I2. 
opinion given by the Law Officers John Holker and Hardinge Giffard on 23 July I 878 echoed Cockburn's position: acts done 'under the authority of so-called martial law' were justifiable only if necessary for the preservation of the state. They could not be given legal sanction by drumhead courts 'nor any other such tribunal'. The instructions given to the commissioners had been improper, since they were 'directed to do acts unnecessary for the restoration of order and having operation intended to continue after order was restored'. The Law Officers advised that as soon as the danger had passed and the necessity for martial law had eased, all those gaoled under it would be entitled to immediate release. An act of indemnity would also be necessary where illegal acts had been committed. ${ }^{\mathrm{I}}{ }^{4}$ Hicks Beach duly advised the Governor to pass an indemnity act. ${ }^{\mathrm{I} 45}$

The indemnity act which was passed indemnified the Governor and commanders of the forces and all acting under them for acts done bona fide in the prosecution and carrying out of the aforesaid military operations against the aforesaid enemies or rebels. ${ }^{146}$ The legislation said nothing, however, about the sentences of those imprisoned by the commissioners. When the Colonial Office questioned this in November 1878, Attorney General Upington admitted that the legislation might not render the continued incarceration of the prisoners valid after the end of martial law, and recommended passing a short act to legalise this. In his view, it would be out of the question 'to release the convicts who have all been guilty of the open acts of treason in which they were captured red-handed', and he felt that commuting the sentences would have a disastrous effect on 'the Kafir mind' which would see it as a sign of weakness. ${ }^{\text {I } 47}$ The necessary legislation was duly passed. ${ }^{\text {I } 48}$

This episode provided the fullest discussion of martial law between the Jamaica controversy and the Anglo-Boer war. On this occasion, different views on what kind of approach to take were taken by the ministry, the Governor, and the metropolitan authorities: on this occasion, it was the common law view, stressed by the Law Officers in London, which prevailed over both the Governor's attempt at

\footnotetext{
${ }^{\text {I } 44}$ Law Officers' Opinion, 23 July I $878, \mathrm{CO} 879 /$ I $3 / 5_{5}$, No. I79, p. 30 I.

${ }^{145} \mathrm{CO} 879 /$ I $3 / 5_{5}$, No. 204, p. 34 I.

${ }^{146}$ The Military Operations Indemnity Act, No. 23 of 1878 .

${ }^{147}$ Upington to Colonial Secretary, 3 January I 879, CO 48/489/27 I 6.

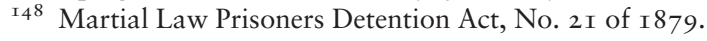


a hybrid form of legalism and the ministry's desire to use unconstrained martial law power.

\section{Detention without Trial}

The general policy adopted during the frontier wars was to try rebels in martial law courts and to come to terms with enemies after having subdued them. Throughout this period, outside of times of martial law, a number of African leaders were also detained, though without the kind of ad hominem legislation which would later become common. For instance, after Ngqika had secured his position as the chief of the Rharhabe clans of the Xhosa with Somerset's help in the battle of Grahamstown in I8I9, his main opponent Makhanda (also known as Nxele) was removed to Robben Island. ${ }^{\mathrm{I} 9}$ Over thirty years later, when Mlanjeni began to alarm the authorities with his prophecies, he was regarded as exerting a similar influence over the people as Nxele had, and plans were made to deal similarly with him. ${ }^{\text {I50 }}$ "If you catch this Mahomet let him be right well secured', Governor Smith wrote to his administrator in British Kaffraria, 'and he shall very speedily find himself in Robben Island.' ${ }^{51}$

Colonial administrators were aware that legal cover could be supplied easily enough. This is evident from Sir George Grey's response to an inquiry from Lord Canning, Governor-General of India, whether the last Mughal emperor of India, Bahadur Shah Zafar, could be banished to the Cape after his trial by a military commission in the wake of the I857 'Indian Mutiny'. Responding to Canning's concern that special legislation would be needed to authorise it, Grey responded that, if Zafar arrived in South Africa, and 'this difficulty presents itself, then, as the Proclamation of the High Commissioner in British Kaffraria has the force of law, I shall issue the necessary Proclamation, and then place him in King William's

${ }^{1} 49$ See Julia C. Wells, The Return of Makhanda - Exploring the Legend (Scottsville, University of KwaZulu-Natal Press, 20I2).

${ }^{150}$ Peires, The Dead Will Arise, pp. I-2; Crais, White Supremacy and Black Resistance, p. 175 .

${ }^{\text {I5 }}$ PP I85I (1334), enc. 2 in No. 2, p. I5: as Peires points out (The Dead Will Arise, p. 8), he may have had in mind the lunatic colony in that place. 
Town.' ${ }^{152}$ For its own dissidents, however, the Cape authorities had other tools available. Another leader who ended his days on Robben Island was Maqoma. Within two years of his release from imprisonment in 1869 , the authorities were troubled by his attempts to recover his old lands, which might 'give an immense deal of trouble to the Government'. ${ }^{\text {I53 }}$ Since he was regarded as a prisoner still on parole, it was easy enough for the government to return him to Robben Island.

The Gcaleka chief, Hintsa, suffered an even worse fate at British hands. During the sixth frontier war, British forces had crossed the Kei into his territory, suspecting him of encouraging the Ngqika warriors and of harbouring stolen cattle for them. At the end of the war, when Hintsa sought to make peace with D'Urban, the Governor demanded an immediate payment of 25,000 head of cattle, with a further 25,000 to be delivered a year later. He also wanted Hintsa to punish those who had killed two British subjects and to deliver two hostages as security. ${ }^{\mathrm{I} 4}$ When Hintsa failed to produce the killers, D'Urban declared that 'I have a full and just right to consider and treat him as a prisoner of war, and send him to Cape Town.' ${ }^{155}$ However, he opted instead to allow Hintsa to remain where he was, on condition that he assist the troops in locating the killers and collect the cattle. While riding out with Smith and George Southey and a corps of guides to collect the cattle, Hintsa made an attempt to escape. Both Smith and Southey gave chase, which ended in the chief being shot in the head. According to Smith, the chief had been warned that he would be shot if he tried to escape, and he was killed by Southey when he refused to surrender and raised an assegai. ${ }^{156}$ Other reports indicated that Hintsa was hit several times before the fatal shot, and had cried out for mercy before he was killed; and that Southey had cut off one of his ears as

${ }^{152}$ Grey was equally confident that the Cape assembly would pass a law 'giving the same effect to the sentence passed upon the King of Delhi, as it would have had if it had been passed by the Supreme Court of this Colony'. Grey to Labouchere, I I November I $857, \mathrm{CO} 48 / 384$, f. 279. In the end, Zafar was exiled to Rangoon.

${ }^{153}$ Barkly to Kimberley, 2 December I 87I, WCA GH 23/3 I, p. [346]. His incarceration on Robben Island was authorised by Act 25 of I 857; see also Price, Making Empire, p. 353. For the background, see Timothy J. Stapleton, 'Reluctant Slaughter: Rethinking Maqoma's Role in the Xhosa Cattle-Killing (I853-I 857)', International Journal of African Historical Studies, vol. 26:2 (I993), pp. 345-369.

${ }^{154}$ PP 1836 (279), enc. 7 (2) in No 3, p. 33 at p. 35.

${ }^{155}$ PP 1836 (279), enc. I 2 (C) in No. 3, p. 42.

${ }^{156}$ Smith to D’Urban, I 8 May I 835, PP I 836 (279), enc. I 8 in No. 3, p. 48 at p. 49. 
a trophy. ${ }^{\mathrm{I}} 57$ The killing was followed by an outcry, and, in July I 836 , D'Urban ordered a military court of inquiry to investigate the circumstances of Hintsa's death. ${ }^{158}$ Hintsa's fate continued to weigh on the mind of his son, Sarhili: it was one of the reasons why he refused to respond when Frere summoned him after the outbreak of the war of Ngcayecibi. ${ }^{\text {I59 }}$

The legal basis for holding enemy chiefs was often unclear, given the jurisdictional ambiguities in these territories. During the seventh frontier war, the Ngqika chief Sandile was held without trial for two months in I847. He surrendered in October, after being given guarantees respecting his 'personal life', and agreed to go to Grahamstown, under the impression that he would be able to air his grievances and negotiate terms with the British. ${ }^{160} \mathrm{He}$ soon discovered that Pottinger regarded him simply as a prisoner. Pottinger had made plans as early as June for Sandile to 'be placed in confinement as a state prisoner, pending the pleasure of Her Majesty's Government'. ${ }^{\text {I6I }}$ Two months later, he had proclaimed Sandile to be a rebel who had 'set at nought the paramount power which he had acknowledged', even though he was an African chief living in an area not under British rule. ${ }^{162}$ The legal basis of his detention was unclear: martial law was not in operation in the Eastern Cape, and if he was to be regarded as a rebel, rather than as a prisoner of war, he should have been charged or freed. ${ }^{163}$ But given that there was no likelihood that a habeas corpus application would be brought on his behalf, such legal niceties did not trouble the men on the ground. After two months' incarceration, he was finally released by Pottinger's successor as Governor, Sir Harry Smith, in a manner calculated to humiliate the chief. When Sandile was brought before the new Governor, he was (in his own words)

${ }^{157}$ Lester, Imperial Networks, pp. I $24 \mathrm{ff}$.

${ }^{15} 8$ Proceedings of the Court of Inquiry on the Fate of the Caffer Chief Hintza (Cape Town, I837).

${ }_{159} \mathrm{CO} 879 / \mathrm{I} 2 / 3$, No. 74 , p. 172.

${ }^{160}$ Le Cordeur and Saunders, The War of the Axe, pp. 217, 220-224, 234; Mostert, Frontiers, p. 927.

161 PP I 847-48 (9I2), enc. I in No. 26, p. $88 . \quad{ }^{\text {I62 }}$ PP г $847-48$ (9I2), No. 6, p. I 26.

${ }^{163}$ When Pottinger contemplated reimposing it in mid I 847 , it was not to authorise the detention of state prisoners, but to raise troops. Le Cordeur and Saunders, The War of the Axe, p. I30. 
'dictatorial in the extreme'. ${ }^{164}$ On asking Sandile who was his paramount chief - and being told it was Sarhili - Smith shouted in response, 'I am your paramount chief, and the kaffirs are my dogs!' ${ }^{\text {I65 }}$ As a sign of his submission to his new overlord, Sandile was made to kiss the Governor's foot, and he was told that he was to surrender all his arms, or he would again be hunted down.

If Pottinger and Smith were untroubled by the legal basis on which they held an enemy chief, the matter was debated more in I 877 during the ninth war, when the Cape authorities contemplated holding Sarhili as a state prisoner. After destroying his kraal and driving his followers over the Mbashe River, they pondered whether they could try him for murder or rebellion; but they remained unsure whether he was to be regarded as an independent chief or as in some sense 'under' the British government, which had permitted him to return to Galekaland, albeit without becoming a subject. ${ }^{166}$ In addition, as Attorney General Stockenström pointed out, there were 'grave technical difficulties' in the way of trying him for any acts committed outside the colony, though he felt that the government would be justified both in depriving him of the land to which he had been allowed to return and in incarcerating him. ${ }^{167}$ Lord Carnarvon agreed that it would be impossible to try the chief, but thought that he could be held as a state prisoner when captured. ${ }^{\mathrm{I} 68}$ The point became moot when, with the onset of rains, Commandant Griffith gave up his pursuit of the chief. ${ }^{\text {I69 }}$

The legality of holding men whose status as rebel subjects or enemy aliens was unclear was more directly addressed at the end of the Griqua rebellion in 1878 , when 140 prisoners were captured in Kokstad and removed to Cape Town. Neither of these places was under martial law, and no warrant was issued for their detention. Instead, Attorney General Upington was asked to take charge of them, and when they were sent to the Amsterdam Battery, verbal orders were given to the gaoler by the Colonial Secretary, J. Gordon Sprigg, to hold them. From

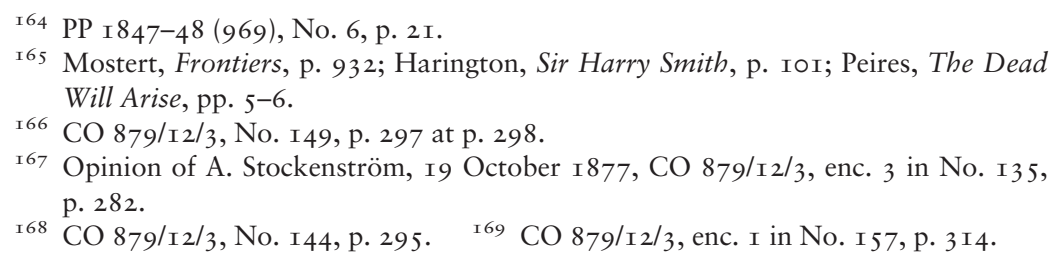


the moment of their arrival at the Cape in June, their case was taken up by the Cape politicians Saul Solomon and Andries Stockenström. At the end of February, they had obtained a writ de homine libero exhibendo on behalf of two detainees, Willem Kok and Nathanial Balie, in a test case seeking their liberation. Making a verbal return to the court, Upington stated that they had been arrested as prisoners of war, and produced an affidavit from the Undersecretary for Native Affairs, which stated that the release of a large number of prisoners taken in war would damage the prospects of peace. ${ }^{170}$ The status of the rebels was central to the case: if they were British subjects, they could not be held as prisoners of war but had to be tried. At the first hearing, Upington claimed there was a state of war with the nation of 'Adam Kok's Griquas', who were not British subjects, since the Griqualand East Annexation Act had not yet been implemented, and since their Raad had never agreed to the cession and had resisted British authority. ${ }^{17 \mathrm{I}}$

In considering how to treat the Griquas, the court bore in mind a recent case which had raised similar questions, which had been tried by Chief Justice Henry de Villiers. This was the case of Nehemiah Moshoeshoe (son of the paramount chief Moshoeshoe), who had been charged with sedition for acts committed in Griqualand East. In I 865, the Griquas had driven Nehemiah out of Matatiele, an area in the north of Nomansland where he had settled in I859, and an area which he was determined to recover. In September 1876 , his followers clashed with the British Resident, Capt. Blyth, in Matatiele in a very minor skirmish. ${ }^{172}$ Those who resisted authority were captured, and a court of inquiry was held by the resident magistrate. Nehemiah was found to be the instigator of a rebellion and was arrested for trial. After some hesitation about where he should be tried, ${ }^{\mathrm{I} 73}$ he was eventually tried on charges of sedition, riot and assault before the Chief Justice in King William's Town - 'clear evidence being forthcoming that he is

${ }^{170}$ In re Willem Kok and Nathaniel Balie, in Eben J. Buchanan, Cases in the Supreme Court of the Cape of Good Hope during the Year I 879 (Cape Town, Juta, I880), p. 45 [Juta Reports, I879, p. 45] at pp. 49-50.

${ }^{171}$ Cape Times, I March I879, p. 3.

${ }^{172}$ PP 1877 (c. I748), No. II9, p. I48; No. I 26, p. I 55.

${ }^{173}$ See PP I 877 (c. I748), No. I 5 O, p. I 86; enc. I in No. I72, p. 225 ; PP I 877 (c. I776), No. I I, p. 6; enc. in No. 43, p. 55. 
a British subject'. ${ }^{174}$ Although the offences were committed outside the colony, the Cape court was able to try the case on the assumption that he was British, by virtue of its extraterritorial jurisdiction. In the event, Nehemiah was acquitted by the jury, which found that - even if he was a British subject - Blyth had no authority as chief magistrate in this area. ${ }^{175}$

The relevance of this case for the Griqua prisoners was this: if Nehemiah was treated as a subject who could be tried for sedition, why should the Griqua prisoners not also be treated as subjects and put on trial? Stockenström pointed to a wealth of evidence which showed that the British had regarded them as such. This included Sir George Grey's letter of I 86I that he would not assent to the Griquas moving to Nomansland as an independent people, but would only permit them to come as British subjects. ${ }^{176}$ It was also evident from the affidavits given to the court that the Griquas had been treated as rebels, rather than as enemies. Indeed, Upington himself had thought that they were British subjects when they took up arms, but did not want to prosecute them as such, since he had no conclusive documentary evidence of their status. Since he considered that their discharge from custody in the event of the failure of any prosecution against them would be disastrous, he opted to hold them as prisoners of war. ${ }^{177}$ Upington did not seem concerned by the fact that a state of war no longer existed, which might justify their continued incarceration: as he explained in October, in another context, 'It has been the custom in this Colony, rightly or wrongly, to detain without legislative enactment, after cessation of hostilities, prisoners of war whose release would be dangerous to the public safety. ${ }^{\text {I7 }}$

${ }^{174}$ PP 1877 (c. I776), enc. in No. 96, p. I33. The indictment is in Natal Witness, I May I 877, p. 3 .

175 Cape Times, 9 May 1877, p. 3. The result was welcomed in many sections of the press: see Leselinyana La Lesotho, I June I877, p. Io; Natal Witness, I I May I 877, p. 3 .

${ }^{176}$ Report of the Select Committee on Native Affairs (Cape Town, I874), CPP A.I2-'73, p. I43. However, as Fairfield pointed out, 'a High Commissioner cannot naturalise aliens by his own authority': it required legislation or annexation. Minute 25 April I 879, $\mathrm{CO}_{4} 8 / 489 / 6$ I 59 .

177 Minute of Attorney General Thomas Upington, 3 March I 879, CO 48/489/6I 59 .

${ }^{178} \mathrm{CO} 879 / \mathrm{I} 6 / 5$, enc. 3 in No.257, pp. 540-54I, referring to the detention of the Zulu king Cetshwayo, discussed in Chapter 3 . 
From the beginning, it was clear that the application for the writ would be dropped if the detainees were guaranteed an early trial. Upington at first refused to give any undertakings on this point without an admission by the detainees of their subjecthood, but later indicated that he would be able to prove their status and so was prepared to go to trial. With this in prospect, the court was prepared to remand them to prison awaiting trial, while still allowing them the option to renew their application for a discharge. It was at this point that Upington backtracked, and obtained a postponement to bring affidavits to show that they were indeed prisoners of war. However, when the affidavits arrived, the most significant of them - Matthew Blyth's - showed conclusively that he had treated them as subjects all along. When the court reconvened in the middle of May, the Attorney General accordingly proposed that they be tried. He was now prepared to consent that they be released, albeit in order to be re-arrested; but Stockenström, who had agreed to a trial provided it was speedily brought, insisted that judgment should be given in the case before them, since he had received an undertaking from the crown that this would be a test case for all the men captured. ${ }^{179}$

Giving judgment, Chief Justice de Villiers noted that, if the men were prisoners of war - which was the crown's original claim - then the court could not interfere. However, he was unconvinced that they were such prisoners. For more than fifteen years, the British had exercised de facto jurisdiction over Griqualand East, and ever since Adam Kok's death it had been 'treated in all respects as a dependency of this colony'. ${ }^{180}$ Nor was de Villiers convinced that the skirmishes with the Griquas - which had been described in the affidavits as a 'rebellion' - amounted to a state of war. Even if there had been one, it was admitted that it had ended. This (the Chief Justice noted) must have happened on the day the Griquas were defeated, which was before the detainees were arrested. De Villiers's analysis of the events from the affidavits showed that Blyth - in seeking to charge Lodewyk Kok and Adam Muis with offences - had purported to exercise the kind of jurisdiction over the Griquas which could be exercised only over British subjects. If they were not such subjects, they were perfectly within their rights to resist. On the other hand, if they were subjects,

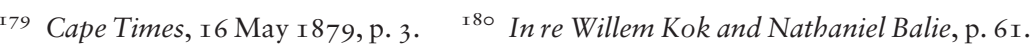


then the return to the writ which stated that they were prisoners of war was false. Turning to the court's power, the Chief Justice emphasised 'the bounden duty of the Court to protect personal liberty whenever it is illegally infringed upon'. ${ }^{\text {I8 }}$ De Villiers's judgment was a ringing endorsement of the rule of law; and it was one which this liberal judge would refer back to on numerous subsequent occasions. In making his judgment, de Villiers addressed the argument that the country was in such an unsettled state, and the detainees men of such a dangerous character, that the court should not exercise a power which 'under ordinary circumstances might be usefully and properly exercised'. It was an argument he found unappealing. In a phrase much quoted thereafter, he declared,

The disturbed state of the country ought not in my opinion to influence the Court, for its first and most sacred duty is to administer justice to those who seek it, and not to preserve the peace of the country. If a different argument were to prevail, it might happen that injustice to individual natives has disturbed and unsettled the whole tribe, and the Court would be prevented from removing the very cause which produced the disturbance ... The Civil Courts have but one duty to perform, and that is to administer the laws of the country without fear, favour or prejudice, independently of the consequences which may ensue. ${ }^{182}$

In the same judgment, he held that 'the rights of personal liberty, which persons within this colony enjoy, are substantially the same, since the abolition of slavery, as those which are possessed in Great Britain'. ${ }^{183}$ For good measure, he added that, although there were times when martial law might be proclaimed, it could be justified only by necessity, and was exercised by the military at their peril, without any assistance from civil courts.

After de Villiers had ordered the detainees' release, they were re-arrested, with a view to putting them on trial. ${ }^{184}$ The case attracted attention in London. In July, W. H. James raised their case in the Commons, and in the press, asking why they were now to be tried as

\footnotetext{
${ }^{18}$ I In re Willem Kok and Nathaniel Balie, p. 64.

${ }^{182}$ In re Willem Kok and Nathaniel Balie, p. 66. See Albie Sachs, Justice in South Africa (Berkeley and Los Angeles, University of California Press, I973), p. 245; Stephen Ellmann, In a Time of Trouble: Law and Liberty in South Africa's State of Emergency (Oxford, Oxford University Press, I990), p. 2 Io.

${ }^{18} 3$ In re Willem Kok and Nathaniel Balie, p. 64. ${ }^{184}$ Cape Times, I6 July I879, p. 3.
} 
rebels, having been taken first to Cape Town as prisoners of war. ${ }^{.85}$ The Kokstad magistrate Charles Brownlee examined the detainees who had been sent back, releasing many on bail (varying from $£_{5}$ to $£_{\text {IOO }}$ ) and freeing others, and sent affidavits from the prisoners to show that they had been well treated. ${ }^{186}$ Brownlee reported that the situation had calmed since the conviction of Lodewyk Kok for sedition (for a second time) in July. ${ }^{187}$ In the end, a handful of the Griqua rebels were tried. ${ }^{188}$

\section{Conclusion}

During fifty years of frontier wars and rebellions, the authorities in the Cape Colony resorted to extra-legal detention without trial only on the rarest of occasions, as when Sandile was held without any charges for two months in 1847 . On the frontier, captured enemies were more likely to be treated as prisoners of war, and released at the end of the conflict. The kinds of ad hominem detention laws which would frequently be used in much of the empire from the late 1870 s were not passed at the Cape to deal with troublesome enemies of empire on the edges of its jurisdiction. This is not to say that other forms of 'lawfare' were not used: the trials in British Kaffraria of Maqoma, Mhala and Phato in I857-1858 by a special tribunal established under the martial law regime in that possession allowed the imperial state to abandon the procedures and protections found in an ordinary trial, in order to remove the Xhosa chiefs to Robben Island and effectively destroy their power. The legal and constitutional right of the High Commissioner to act in this way here might have been questionable, but there was no forum in which this right could be

${ }^{18} 5$ Parl. Debs., third ser., vol. 248, col. 969 (22 July I 879), col. I 297 (25 July I 879); The Times, 29 July I $879, \mathrm{p} .8$.

${ }^{186} \mathrm{CO} 879 / \mathrm{I} 6 / 5$, enc. 3 in No. 256 , p. 5 I 6 . He reported that 'those who have land have returned to their farms and are cultivating them, others are in service, some are loafing about the canteens in Kokstadt, and several have been imprisoned for drunkenness and disorderly conduct'. PP I880 (c. 2482), enc I (I) in No. I35, pp. 358-359. See also Cape Times, 30 July I 879 , p. 3.

${ }_{187} \mathrm{CO} 879 / 16 / 5$, enc. 3 in No. 256, p. 5 I 6; Natal Witness, 3 I July I 879, p. 2. Lodewyk had not been one of the Cape detainees, having been already imprisoned.

${ }^{188}$ See Samuel James Halford, The Griquas of Griqualand (Cape Town, Juta, I949), p. I73; I. B. Sutton, 'The End of Coloured Independence: The Case of the Griqualand East Rebellion of I 878', Transafrican Journal of History, vol. 8: I/2 (I979), pp. I 8 I200, at p. I95; and Cape Times, 30 July I879, p. 3 . 
questioned, even if the chiefs had had the means to do so. ${ }^{\text {I89 }}$ However, even here, questions were raised by the Cape's Attorney General about how compatible the procedures used were with constitutional principles of the rule of law, which led to lesser punishments being imposed than had initially been contemplated. Moreover, when the Cape authorities did attempt to hold detainees without any form of legal cover, seeking to exploit the ambiguity between prisoner of war status and that of political prisoners, in the case of the Griqua rebels, their power to do so was robustly rejected by the Cape Supreme Court.

By contrast, the Cape did resort to martial law courts to try rebels on a number of occasions. Martial law remained unprovided for at the Cape by the kinds of statutes found in India, and so its use raised the same legal questions as were debated after the Jamaica rebellion. In this location, a view of martial law came to prevail which reflected the common lawyers' position, which sought to subject it to the rule of law. As shown by the debates of 1878 , local political demands for swift exemplary action by use of martial tribunals could be checked within the colony by the legal and constitutional objections raised both by legal officials at the Cape and by imperial officers articulating a Diceyan view of martial law. At the same time, colonial officials accepted that the passage of indemnity acts could not be taken for granted, and that the actions to be indemnified needed to be evaluated for their necessity. The fact that this was so reflected both the political culture at the Cape - where a liberal judiciary and liberal politicians could always raise questions about executive action - and the watchfulness of ministers and officials in London.

${ }^{189}$ For the questions raised, see Price, Making Empire, pp. 333-334, n. 2 I. 